\title{
Towards the Understanding of Hydrogeochemical Seismic Responses in Karst Aquifers: A Retrospective Meta-Analysis Focused on the Apennines (Italy)
}

\author{
Gilberto Binda ${ }^{1}{ }^{1}$, Andrea Pozzi $^{1}$, Alessandro M. Michetti ${ }^{1} \mathbb{D}$, Paula J. Noble ${ }^{2,3, *(\mathbb{D}}$ and \\ Michael R. Rosen ${ }^{3,4}$ (D) \\ 1 Dipartimento di Scienza e Alta Tecnologia, Università dell'Insubria, Via Valleggio 11, 22100 Como, Italy; \\ g.binda2@uninsubria.it (G.B.); andrea.pozzi@uninsubria.it (A.P.); \\ alessandro.michetti@uninsubria.it (A.M.M.) \\ Department of Geological Sciences and Engineering, University of Nevada, Reno, NV 89557, USA \\ Global Water Center, University of Nevada, Reno, NV 89557, USA; mrosen@usgs.gov \\ 4 United States Geological Survey, Carson City, NV 89701, USA \\ * Correspondence: noblepj@unr.edu
}

Received: 26 October 2020; Accepted: 23 November 2020; Published: 26 November 2020

\begin{abstract}
Earthquakes are known to affect groundwater properties, yet the mechanisms causing chemical and physical aquifer changes are still unclear. The Apennines mountain belt in Italy presents a rich literature of case studies documenting hydrogeochemical response to seismicity, due to the high frequency of seismic events and the presence of different regional aquifers in the area. In this study, we synthesize published data from the last 30 years in the Apennine region in order to shed light on the main mechanisms causing earthquake induced water changes. The results suggest the geologic and hydrologic setting specific to a given spring play an important role in spring response, as well as the timing of the observed response. In contrast to setting, the main focal mechanisms of earthquake and the distance between epicenter and the analyzed springs seems to present a minor role in defining the response. The analysis of different response variables, moreover, indicates that an important driver of change is the degassing of $\mathrm{CO}_{2}$, especially in thermal springs, whereas a rapid increase in solute concentration due to permeability enhancement is observable in different cold and shallow springs. These findings also leave open the debate regarding whether earthquake precursors can be recognized beyond site-specific responses. Such responses can be understood more comprehensively through the establishment of a regional long-term monitoring system and continuous harmonization of data and sampling strategies, achievable in the Apennine region through the set-up of a monitoring network.
\end{abstract}

Keywords: karst aquifer; hydrogeochemistry; water quality; earthquake; Apennines

\section{Introduction}

Major earthquakes (Mw 6.0 and above) are catastrophic events that can dramatically impact human beings, human infrastructure, and the environment [1]. Earthquake ground motion and ground rupture can affect the water chemistry and flow rates of aquifers in the epicentral areas and cause problems for emergency management, as well as longer term issues for water district managers [2,3]. The number and quality of case studies worldwide that have reported seismically induced groundwater anomalies (i.e., changes relative to background levels), discovered by sampling following major shocks [2,4-8], has increased exponentially in the past decades. The role of fluids in the seismogenic processes is attracting the attention of the scientific community. Likewise, groundwater resources are vulnerable 
to seismic hazards, as supply and water quality can potentially be impacted either by transient or permanent changes to the aquifer [9].

Coseismic changes in water quality and aquifer flow have been noticed since ancient times, in the form of: sudden increase/decrease in spring flow, hydrological changes in streams and water table level in wells, increase in contaminants from spring discharge and also increase in the emanation of deep gases [2,10-12]. The discipline of earthquake hydrogeology has shed light on how earthquakes can affect water resources, but most of the work has focused on the alteration of hydrological flow and hydraulic pressure [13-15]. Less is known about the chemical changes in groundwater and mechanisms affecting these changes. To our knowledge, the first published observations of coseismic chemical responses were conducted in the late 1960s [16], followed by case studies of hydrochemical anomalies reported worldwide during events in 1990s and 2000s [17-21]. It seems that in recent years, knowledge about earthquake effects on water resources has advanced as more precise and inexpensive monitoring systems have become available. However, the mechanisms driving changes are still not clear, and responses vary functionally between localities due to aquifer-specific features. Hydrogeochemical responses to seismicity do not necessarily occur synchronously nor uniformly across the epicentral region of strong earthquakes, and are dependent on crustal response to shocks, style and amount of faulting, aquifer attributes, and processes both internal and external to the affected aquifer systems.

Understanding the mechanisms and processes affecting groundwater resources will help to manage the response following strong seismic events and to assess if possible reliable precursors can be proposed on a regional scale. Also, evaluating the responses of aquifer and surface water bodies to seismic events serves as a preliminary step in understanding whether the aqueous chemical changes observed can also be preserved as geochemical signatures in geologic archives (i.e., in soil or sediment), which can serve as a proxy for recognizing paleoseismic events [22].

The seismically active Italian Apennines, especially in Central Italy, are the subject of a large number of studies. Despite the relatively small geographical extent, there is a relatively high-density collection of hydrochemical data related to seismic events, including observations of coseismic dissolved gas increases, changes in carbon isotope values, and increased trace element concentrations. Short-term responses directly following mainshocks are common (especially during the last 30 years, e.g., [2,11,23-25]). Nonetheless, the vast majority of studies are localized, measuring limited chemical parameters, generally for a single aquifer or earthquake, and, so far, a general review and analysis of hydrogeochemical responses in the Apennines, analyzing the last big seismic sequences, are not reported in literature. Even on a global scale, few studies analyze changes in more than a single earthquake crisis [26]. Two combined hydrogeological and geodetic datasets for the Apennines Chain of Italy exist, mainly synthetizing the last 15 years $[6,27]$. Collectively, these two studies provide the impetus for this review paper. Herein, we present a meta-analysis of data from Apennines case studies covering 5 seismic sequences during last 40 years to provide an enhanced understanding of the various phenomena causing hydrogeochemical responses to medium and large earthquakes, including the relationship to hydrogeologic and tectonic setting.

\section{Regional Setting and Historical Seismicity}

\subsection{Tectonic Overview and Climate}

The Apennines Chain (Figure 2) developed essentially in Miocene to Quaternary rocks in the hanging wall of the Adria plate subduction [28-31]. The eastward retreat of the subduction zone is the most plausible explanation for the progressive eastward migration of thrust fronts, the foreland flexure (and consequent shift of the foredeep basins), as well as the initiation of extensional processes along the internal Tyrrhenian back-arc basins. In the external part of the Apennines, that is in the Po Basin-Adriatic foredeep (Figure 2), focal solutions of strong earthquakes show thrust fault mechanisms. The largest instrumental events do not exceed Mw 6.1, although both historical and paleoseismological 
evidence suggests maximum magnitude in the order of Mw 6.5 to 7 (e.g., [32]). Conversely, a belt of Quaternary capable normal faults controls the seismicity of the inner part of the chain, with maximum earthquake magnitude in the order of Mw 7.0 (e.g., [33]). Capable normal faults are those faults in which, although not necessarily active historically, are considered capable of producing coseismic surface faulting and macroseismic epicentral intensity of IX to XI MCS (Mercalli-Cancani-Sieberg scale), based on a suite of field and instrumentally determined criteria [34]. In the last 40 years, the Apennines Chain hosted 5 seismic sequences with moderate to strong events, often accompanied by surface fault ruptures. And a record of additional events of catastrophic proportion is reported within the historical time-window (i.e., 1349, 1456 and 1703 seismic sequences [35]).

Climate plays a pertinent role in hydrogeological setting. In the Apennines Chain, the climate is temperate and highly affected by the Mediterranean Sea, with the length and the intensity of the dry summers increasing southward (July is generally the driest month) [36,37]. Mean annual rainfall in the Apennines is about 500-1000 mm along the Tyrrhenian and the Adriatic coasts, while in the highest mountains along the central carbonate ridge it reaches values of 2000-2500 $\mathrm{mm}$ [37]. In the whole area, precipitation easily infiltrates into the Mesozoic limestone outcrops, which characterize large provinces of the Apennines landscape, generating an extensive and well-developed karstic circulation system. This results in a large number of karst springs, which are present throughout the mountain belt $[36,38,39]$.

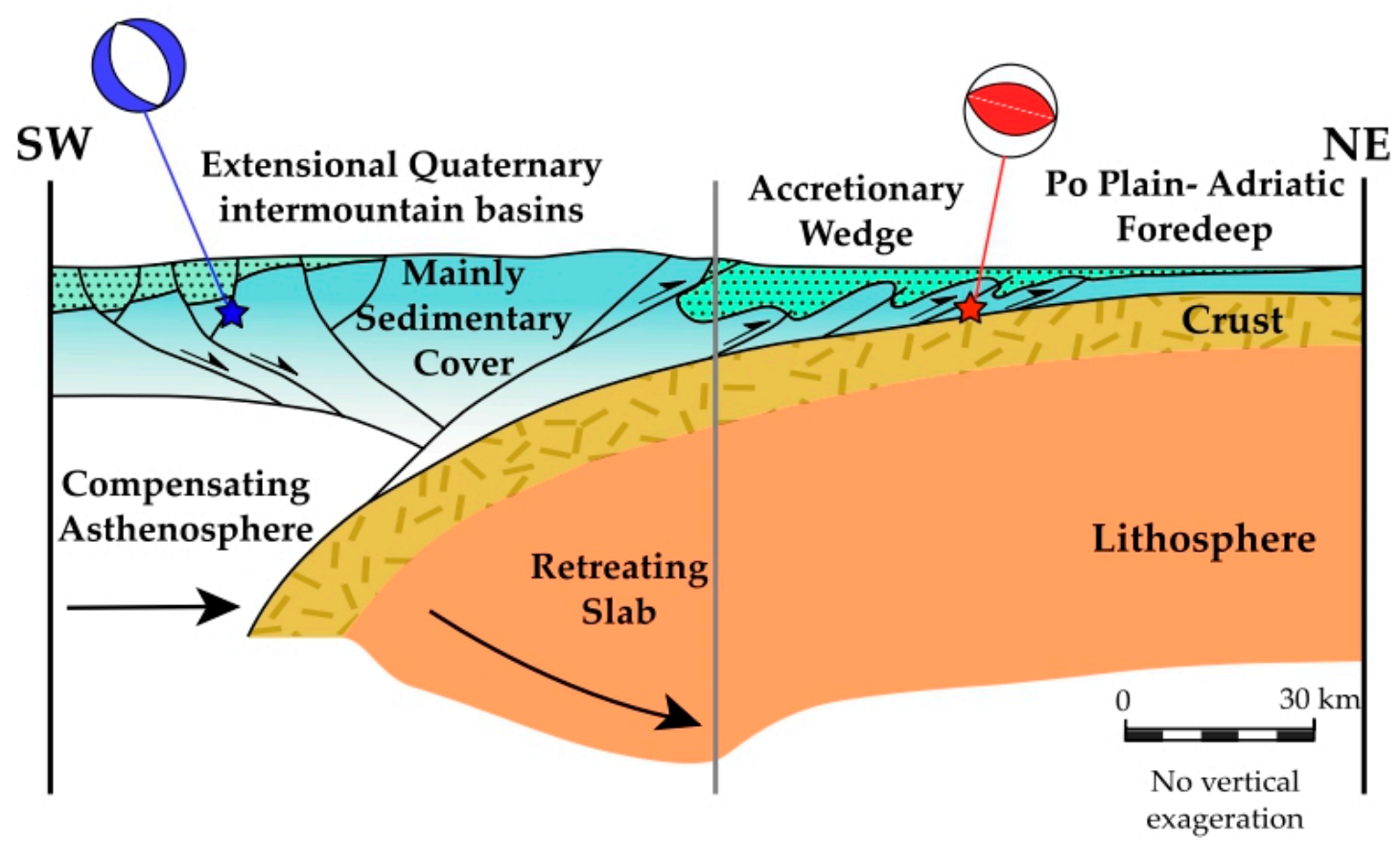

Figure 1. Conceptual cross-section of Central and Northern Apennines (modified after Carminati and Doglioni, 2012 [31], location of the section is reported in Figure 2), showing the generalized tectonic setting of the compressional Adriatic and extensional Tyrrhenian domains (separated by the grey line in the section), which characterize the geodynamic framework of the Apennines mountain belt all along the Italian peninsula. Focal mechanisms of the Emilia 2012 (in red; thrust fault) and Amatrice 2016 (in blue; normal fault) mainshocks are projected onto the cross section as examples of typical, strong (Mw 6 to 7) shallow crustal earthquakes in the Apennines (focal depth in the order of $10 \mathrm{~km}$ ). 




Figure 2. Synthesized tectonic map of Italy and surrounding regions after Carminati et al., 2012 [40]. Numbers in legend indicate, respectively: (1) Adria plate foreland, mostly Mesozoic limestone areas; (2) foreland, Pliocene and Pleistocene deposits (delimited by the $-1000 \mathrm{~m}$ isobath); (3) Po Plain and Adriatic foredeep domains characterized by a compressional tectonic regime; (4) thrust belt units accreted during the Alpine orogenesis in the Alps and in Corsica; (5) areas affected by extensional tectonics: these areas can be considered as a back-arc basin system developed in response to the eastward roll-back of the west-directed Apenninic subduction; (6) outcrops of crystalline basement (including metamorphic alpine units); (7) regions characterized by oceanic crust: newly formed oceanic crust has been recognized in the Provençal Basin (Miocene in age) and in the Tyrrhenian Sea (Plio-Pleistocene in age) whereas old Mesozoic oceanic crust can be inferred for the Ionian Basin; (8) thrusts; (9) faults. The black dotted line indicates the trace of the cross section (Figure 1), while the red stars indicate the epicenters of the 5 recent major mainshocks ( $1=1980$ Irpinia, $2=1997$ Colfiorito, $3=2009$ L'Aquila, 4 = 2012 Emilia, 5 = 2016-2017 Norcia-Amatrice).

\subsection{Regional Geology and Deformational History}

The Apennines are mainly composed of Mesozoic-Cenozoic sedimentary cover derived from the Ligurian oceanic crust and the western passive margin of the Adriatic Plate, and of the NeogenePleistocene piggyback basin and foredeep deposits of the active margin [33,41]. The oldest rocks of 
the exposed Meso-Cenozoic succession are 1.5-2 km thick Triassic shallow water carbonate platform and euxinic gypsum-anhydrite and dolostones with minor halite basin deposits (e.g., Burano Formation Evaporites [42,43]). Afterward, the shallow-water platform domain was broken-up during the lower Jurassic, permitting the development of new platform-basin systems, characterized by downthrown blocks, facilitating the accumulation of limestone, marly limestone and marl. In the platform environment, a late Cretaceous-early Miocene hiatus was followed by deposition of early Miocene paraconformable carbonates deposited along a carbonate ramp, while sedimentation was continuous during the Paleogene in the deeper environment. In the proto-western Mediterranean area, the tectonic regime changed during Eocene-Oligocene, when two subduction systems (the late stage SSE- directed Alpine subduction system and the young NW-dipping Apennines subduction system) became active along the retrobelt of the Alpine orogeny [40]. In this way, two subduction systems, with nearly opposite polarity, were present in a relatively narrow area for a short time (i.e., about $20 \mathrm{Ma}$ [44]).

During the late Miocene, the southern Neotethyan passive margin became involved in the evolution of the Apennines, accreting passive margin sedimentary cover during the "eastward" roll-back of the NW-dipping Apennines subduction system [28]. The Apennines slab roll-back induced subsidence and boudinage of large portions of the Alps, which have been dismembered into the Apennines-related backarc basin: the Provencal and the Tyrrhenian basins (Figure 2) [45].

Within the foreland basin setting, tectonically controlled sedimentary basins were developed. Hemi-pelagic marls, followed by turbiditic siliciclastic sandstones were deposited in the foredeep, ahead of the propagating deformational front $[46,47]$. North-eastward migration of thrust fronts developed different tectonic units that brought carbonate ridges onto turbiditic basins with NW-SE orientation [48]. Normal faulting appears to have been ongoing during the whole Quaternary and is still active today, producing one of the most seismically active provinces of the Mediterranean region (Figure 1). The external (eastern) sector (Adriatic Domain) is characterized by normal heat flow, negative Bouguer gravity anomaly, a crustal thickness of about $35 \mathrm{~km}$ and a compressional seismicity characterized by hypocentral depths of 8-14 km. In contrast, the internal (western) sector (Tyrrhenian Domain) of the Apennines is characterized by thinned crust (20-25 km), high heat flow and $\mathrm{CO}_{2}$ degassing, positive magnetic anomalies, shallow crustal earthquakes (6 to $10 \mathrm{~km}$ of focal depth), and positive gravity anomaly $[39,49,50]$. In this sector, in fact, the Apennine chain is presently affected by crustal delamination, with melts from the mantle wedge feeding active and quiescent volcanic systems; extensive alkaline K-rich volcanic systems are located in the Roman, the Neapolitan areas, as well as in Sicily [51,52], whereas silicic volcanic systems are present in Tuscan Magmatic Province [36,53].

\subsection{Main Hydrogeochemical Features}

In the Italian peninsula, the most important regional aquifers are located in the Apennines, along the Tyrrhenian margin of the mountain belt [39]. Central Italy, in particular, hosts many regional karst aquifers with high flow rates, reaching values up to $20 \mathrm{~m}^{3} / \mathrm{s}$ [38,39]. These aquifers are important sources of drinking water, feeding major metropolitan areas and bottling plants (Italy is the top country in Europe for production and per-capita consumption of bottled natural mineral waters [54]). Moreover, a high number of thermal springs, including thermal spas for health treatments (well documented since the Roman times) are present along the Apennine chain [55]. For these reasons, the area is well investigated and monitored regarding the chemical quality of the main regional aquifers, including both cold and thermal waters, which has allowed for documentation of transient and long-term hydrogeochemical changes during seismic crises.

Four main types of aquifers are present in the area:

- karst carbonate litho-structural units, which can be considered the main reservoir of freshwater, characterized by a dense fault system and a widespread fracture-grid that supports infiltration of rainfall and circulation of water. The aquifers are generally hosted by Mesozoic formations made up of limestones, marly limestones and dolostones; 
- alluvial aquifers hosted by Upper Jurassic to Early Oligocene basin deposits of pelagic limestones, marly limestones, and siliciclastic deposits;

- volcanic deposits, hosted in the volcanic complexes belonging to potassic series (e.g., Roman and Neapolitan areas) and silicic lavas (e.g., Tuscany); often geochemical anomalies regarding trace elements are reported in these aquifers (e.g., As, Li, U [53,55]);

- $\quad$ evaporitic sequences aquifers, hosted in the Triassic dolostones and evaporites [56,57].

The tectonic setting of the area affects the spatial distribution and depth of the aquifers. There is, in fact, a discontinuity in aquifers from east to west. The eastern sector preserves the compressional structural features of the Adriatic Domain and the hydrogeology is characterized by the presence of vast recharge areas, with only a few important springs discharging most of the water flowing through the aquifer, causing similar temperatures of water in springs and in the infiltration areas [58]. In contrast, in the western sector, where the compressional belt is disrupted by important extensional structures of the Tyrrhenian Domain, the lower aquifer is partly buried under a low permeability cover (clays, shales, and marls) and is characterized by discontinuous recharge areas corresponding to the outcrops of the carbonate-evaporite formations [39]. Consequently, the western sector has a widespread occurrence of thermal waters with high $\mathrm{pCO}_{2}$ values, connected with high regional $\mathrm{CO}_{2}$ flux derived from a deep mantle related source $[39,50]$. Their composition was considered consistent with a mixing of two water bodies: a shallower component (carbonate component) equilibrated with calcite and dolomite and a deeper one (selenite component) circulating in the Evaporitic Triassic basement [55]. Hydrogeochemical facies of most of the springs, in fact, belong to the Ca-Mg- $\mathrm{HCO}_{3}$ facies, while part of the collected waters presents a higher load in $\mathrm{SO}_{4}$, derived mainly from evaporitic aquifers (Figure 3).

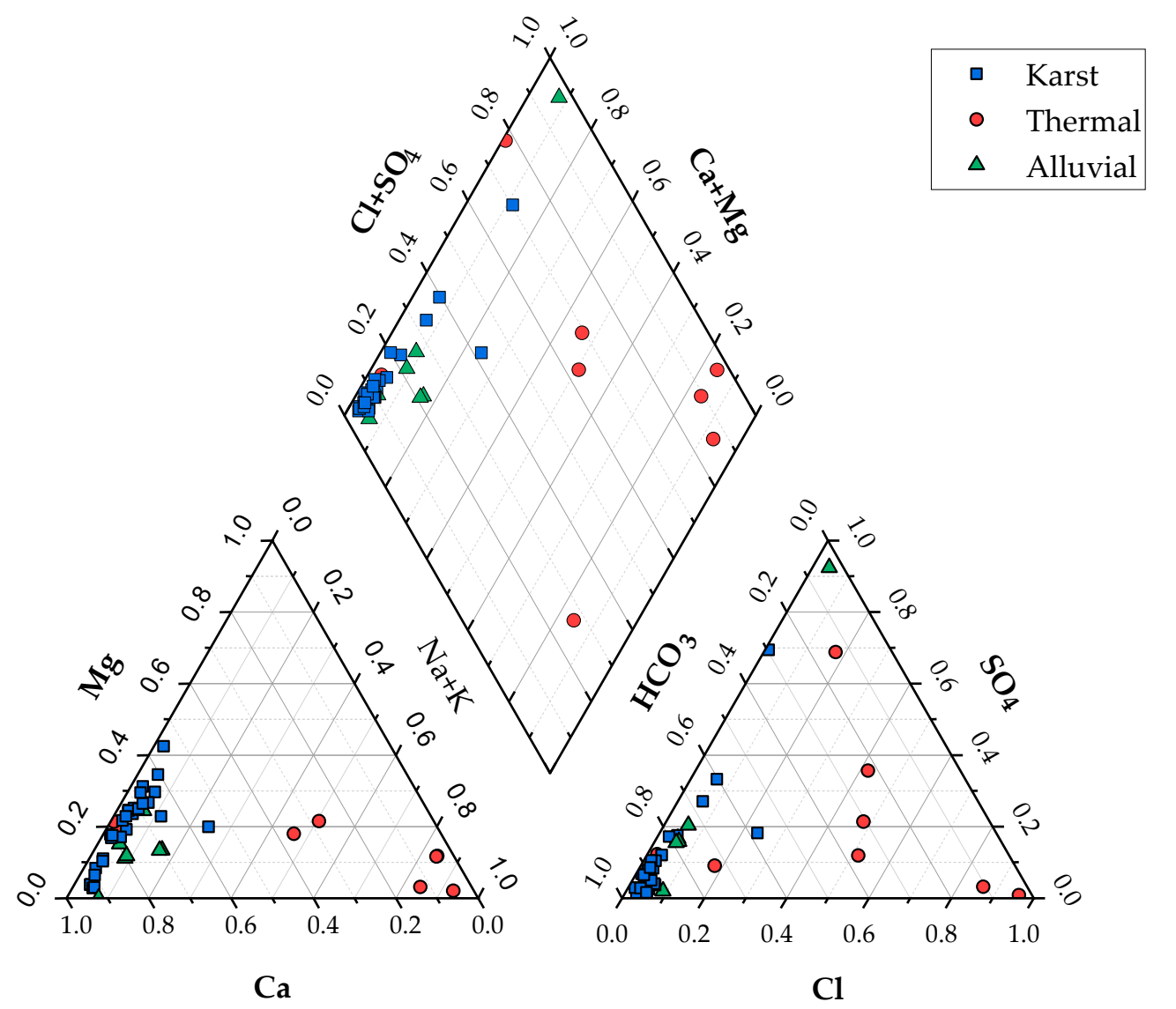

Figure 3. Piper diagram of the average concentration of dissolved ions for 63 springs selected for the meta-analysis (where major-ion data are available). 
Moreover, shallower alluvial aquifers are present in the Apennines, generally hosted in recent detrital alluvial and lacustrine deposits. These alluvial aquifers represent a hydrogeochemical facies similar to the karst one (generally slightly enriched in $\mathrm{K}$ and $\mathrm{Na}$ ) but are sourced from shallower recharge areas, which can be demonstrated by water isotopes [59,60].

In this setting, such a variety of aquifer types are located in a relatively small and seismically active area. Therefore, geochemical markers of the different aquifers can be reliable tools to understand the causes of changes in water chemistry related to seismic activity (i.e., water mixing can be easily observed in the case of aquifer breaching).

\subsection{Major Recent Earthquake Sequences}

A significant cluster of strong seismic sequences has impacted the Apennine Chain over the last 40 years; 5 sequences with mainshocks of magnitude greater than Mw 6 have struck this area (Figure 4), 4 of which are associated with the Tyrrhenian Domain and one (2012 Emilia) with the Adriatic Domain:

- 1980 Irpinia: on 23 November 1980, a large (Ms 6.9, among the strongest earthquakes reported in the Italian catalogue) normal-faulting earthquake occurred in the southern Apennines, within the Tyrrhenian Domain. The event caused the almost total destruction of 15 villages and about 3000 fatalities [61];

- 1997 Colfiorito: this seismic crisis started on September 1997 and lasted about six months, affecting the Umbria Marche province within the Tyrrhenian Domain. The activity began with two high-angle, normal-faulting surface rupturing events of $\mathrm{Ml}=5.6$ and 5.8, presenting a total of five seismic shocks (Ml value $>5 ;[62,63]$ ) and hundreds of less intense shocks. The hypocenters of the entire seismic sequence were at a depth of 5-10 km in the shallow crust, except for one strike-slip event at depth of about $51 \mathrm{~km}$ that occurred on $26 \mathrm{March}, 1998(\mathrm{Ml}=5.3)$ [57];

- 2009 L'Aquila: on 6 April 2009, a Mw 6.3, normal surface-faulting earthquake struck the town of L'Aquila and the surrounding areas in Central Italy (Tyrrhenian Domain), causing 308 fatalities. The shaking in the epicentral area reached a maximum intensity of IX-X on the MCS scale and a maximum peak ground acceleration as high as $0.65 \mathrm{~g}$. The mainshock was followed by thousands of aftershocks, seven of which presented magnitude greater than Mw 5.0 [64].

- 2012 Emilia: an $\mathrm{Ml}=5.9$ mainshock struck the northern part of the Modena province, in the Northern Apennines foredeep setting (Adriatic Domain), on 20 May 2012. This was followed by a second mainshock of $\mathrm{Ml}=5.8$ event on 29 May and five aftershocks characterized by $\mathrm{Ml}$ greater than 5; the entire sequence shows low-angle, reverse fault focal mechanisms. Historical seismicity catalogues indicate that at least 26 shocks with Ml between 4 and 5.5 occurred in roughly the same epicentral area from 1200 to 1975 [32,65].

- 2016-2017 Norcia-Amatrice: The seismic sequence started with the Amatrice Mw 6.0 mainshock on 24 August 2016, nucleated at the boundary between the Laga and Vettore normal faults (Umbria and Lazio regions; Tyrrhenian Domain). After two months, two new mainshocks of Mw 5.9 (Visso) and Mw 6.5 (Norcia), on 26 and 30 October 2016, respectively, ruptured the Vettore fault system; all these events generated coseismic normal fault scarps. This sequence lasted for months, causing nearly 300 casualties, significant damage in numerous towns, and leaving more than 20,000 homeless [66-68].

Moreover, various other events of significant magnitude were reported in historical accounts, which induced important hydrogeological effects. Hydrogeochemical changes of local aquifers during these historical events are reviewed in the section that follows. 


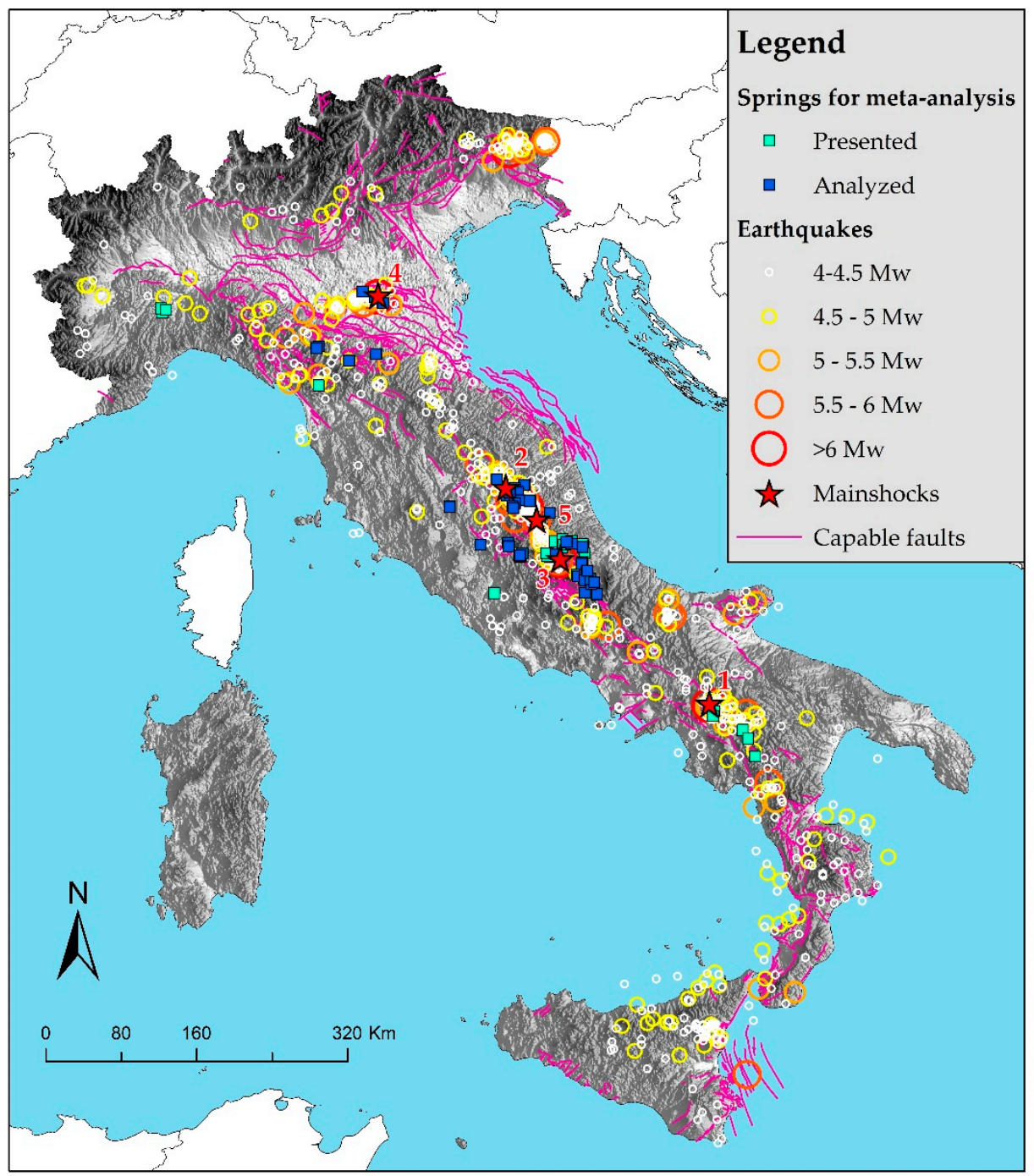

Figure 4. Location map including the trace of capable faults (from ITHACA dataset [69]), epicenters of Mw > 4 seismicity recorded during 1975 to 2019, and the monitoring points included in this review. Red stars indicate the epicenters of the 5 recent major mainshocks $(1=1980$ Irpinia, $2=1997$ Colfiorito, $3=2009$ L'Aquila, 4 = 2012 Emilia, 5 = 2016-2017 Norcia-Amatrice).

\section{An Overview on the Published Studies}

Changes in hydrochemistry correlated with seismicity are reported worldwide in different tectonic and hydrogeological settings. Literature on chemical changes in karst aquifers is rich in case studies that largely cover single seismic sequences with sporadic samplings or short-term monitoring. For example, in the Pyrenees, changes in $\mathrm{Cl}$ ion and $\mathrm{Pb}$ isotope ratios were observed before a $\mathrm{Ml} 5.2$ shock [21,70]. The increase of some major ions (specifically $\mathrm{Cl}$ and $\mathrm{SO}_{4}$ ) was also observed after an earthquake in the springs system of Dead Sea Rift Valley [71]. Changes in electrical conductivity (EC) were observed after a shock in the French Alps, as an index of permeability increase and water rock interaction enhancement [72]. Also in Turkey, after a Mw 7.4 earthquake, slight changes in major ion composition as well as an increase in flow and turbidity were observed [73]. These studies exemplify some of the hydrogeochemical responses that have happened in the Apennines of central Italy, which are described in more detail in the following paragraphs. 


\subsection{History of Observed Hydrogeochemical Responses in the Apennines}

Focusing on the setting of the Apennines in Italy, abundant evidence of widespread seismically induced hydrogeochemical responses has been captured through various snapshot and response-based field campaigns. Hydrochemical anomalies include dissolved gas increases, changes in carbon isotope values, and increased trace and major element concentrations. Also, while this meta-analysis is mainly focused on the chemical changes, a large number of studies reported both transient and permanent changes in water level of aquifers, as well as changes in water flow from springs, which are also important observations with which to understand the mechanisms driving the changes (e.g., [6,74]).

Ancient observations in Italy on the effects derived from seismicity in water date back at least to the 1570 earthquake in Ferrara, located a few km east of the 2012 Emilia sequence in the foredeep of the northern Apennines (Adriatic Domain), when bubbling was noticed in various wells [75].

Nearly 200 years after these early observations, a scientific study by Robert Mallet in southern Italy noted the increase in turbidity and water flow in springs after the normal fault earthquake of 1857 in the Val d'Agri Quaternary extensional basin (Tyrrhenian Domain) [75,76].

In the last century, with the development of more precise instrumentation and better knowledge about water chemistry, the first observations of chemical changes correlated with seismicity were performed following the 1968, Mw 6.4, Belice earthquake in in the compressional foredeep setting of southwest Sicily (Adriatic Domain), where some major ions as well as well pH showed changes before and after the shock [77].

Most of the attention in the first studies of the 1960s and the 1970s was focused on the search for relationships between geochemical markers and tectonic or volcanic activity, in order to decipher possible precursory phenomena [77].

Hydrochemical changes were observed during the Ms 6.9, 1980 Irpinia normal surface faulting earthquake the southern Apennines (Tyrrhenian Domain), the largest event in Italy in the more than a century [78]. An anomalous increase in dissolved Rn concentrations in 2 springs in Latium was reported [25], which was interpreted as a result of dilation during pre-earthquake processes. In this case, the hydrochemical anomalies were observed in a location far from the epicentral area (more than $250 \mathrm{~km}$ away). Additionally, slight increases in major ions were reported in springs closer to the epicentral area [79].

The extensional tectonic setting of the southern Apennine belt was then struck again by a moderate seismic event (Val d'Agri, Mw 4.9) in 1996, during which 3 thermal springs were continuously monitored for physicochemical features [80]. Some anomalies were discovered regarding electrical conductivity and temperature. Moreover, Italiano et al. [81] reported changes in gas composition in one spring, indicating an increase in deep degassing.

A rich literature exists concerning the hydrogeochemical responses during the 1997 Colfiorito sequence. A number of thermal springs were monitored in order to understand geochemical sources of anomalies from mantle derived fluids. In fact, the main focus was set on bubbling and dissolved gases [11,57,82]. These results highlighted $\mathrm{CO}_{2}$ degassing on a regional scale, consistent with the extensional tectonics of the Tyrrhenian Domain, which caused a drop in the $\mathrm{pH}$ of the thermal waters as well as changes in the mixing proportions between shallow and deep gaseous components. Some authors also reported changes in major ion composition of the same springs [56,83-86]. Also, some cold springs in the same setting were analyzed for their major ions, and increases of $\mathrm{HCO}_{3}$ and $\mathrm{Fe}$ concentration were detected [87].

In 2000-2001, in the compressional setting of Monferrato (northern Italy, Adriatic Domain), an anomalous increase in temperature of a shallow aquifer was reported after a series of moderate shocks (Nizza Monferrato, including two events of Mw 5.1 and 4.8). This anomaly was investigated through geochemical modeling and explained as enhanced leakage from a confined hot aquifer favored by an increase in pore pressure induced during a seismic swarm $[88,89]$.

Throughout the 2009 L'Aquila sequence, several studies report changes in major ions. Two studies compared pre- and post-seismic values of major ions in different springs of the Gran Sasso karst aquifer system $[74,90]$ and another study reported a decrease in biodiversity of macroinvertebrates in 
a series of springs in the SE part of the Gran Sasso Mountains, which was correlated with changes in major ions [91]. Temperature and water level also showed anomalies during and after the seismic sequence [92]. Moreover, changes in dissolved gas composition in several thermal springs during this seismic sequence were reported, as well as Rn anomalies in proximity to an activated fault [93,94]. A detailed regional study was performed by Chiodini et al. [95], measuring major ions, isotope ratios, and dissolved gases in various springs in the epicentral area. The authors pointed out the strong increase in radiogenic crustal gases (Ar and He), suggesting deep, long-term storage of high-pressure gas in the seismic area.

Additionally, in the deep area of the Gran Sasso Mountain massif, where hydrochemistry of groundwater is constantly monitored (due to the presence of the Gran Sasso National Laboratory, where nuclear physics experiments are conducted), an increase in uranium concentration was observed before the seismic swarm. These anomalies were highlighted as a possible increase in $U$ derived from carbonate dissolution due to $\mathrm{CO}_{2}$ release during the dilation phase before the earthquake mainshock [96,97].

In 2012, during the Emilia Romagna sequence, a preliminary observation of changes in chemistry of dissolved gases was presented by Italiano et al. [98] and then integrated with more hydrochemical data and a longer period of gas monitoring of the same deep wells, highlighting a notable increase in dissolved $\mathrm{CH}_{4}$ and $\mathrm{CO}_{2}$ [65]. Two other notable changes were identified. First, some changes in major ion concentration were observed in samples collected from bottling plants in the northern part of the Apennines [99]. Secondly, an anomaly in $\mathrm{CO}_{2}$ content was noticed and continuously monitored in a thermal spring during this seismic sequence in the Tuscany region, about $100 \mathrm{~km}$ from the epicentral area [100].

During the last seismic sequence that struck the central part of the Apennine belt, in 2016 and 2017, there were 4 studies published with complete analyses of springs and wells in a range of $100 \mathrm{~km}$ from the epicentral area. Each study reported changes in trace element composition. Some studies noted anomalies before the mainshock, and others noted anomalies that occurred during the seismic sequence [101,102]. In contrast, another study analyzing springs in the same general region observed the abrupt increase in various trace metals following each of the mainshocks, followed by a decrease to values similar to the pre-earthquake baseline [2]. A follow-up paper by Barbieri et al. [12] then tried to clarify why some springs showed an effect from deep fluid interaction, interpreting the carbon and carbon isotopic data observed during this seismic sequence. Combining carbon data with $\mathrm{Na} / \mathrm{Li}$ geothermometers, these authors observed that springs that showed responses in terms of carbon isotopes have a calculated $\mathrm{CO}_{2}$ partial pressure at depth similar to that in deep boreholes in the northern Apennines. Thus, these springs are likely to indicate the effects of deep $\mathrm{CO}_{2}$ mixing related with seismicity.

Building on these local and regional case studies, a few works have tried to compare more data, combining responses on different earthquake sequences. One study showed a long time series of inorganic carbon data following both 2009 L'Aquila and 2016 Amatrice earthquake sequences in a system of springs and wells around Rome [103], trying to find similar responses in different sequences. However, while an increase of carbon derived from deep $\mathrm{CO}_{2}$ was observed before the 2009 L'Aquila mainshock, this anomaly was not detected for the 2016 Amatrice earthquake. Another recent study observed the correlation of $\mathrm{CO}_{2}$ degassing and seismicity in a group of springs in the Gran Sasso area during two recent earthquake sequences (i.e., 2009 L'Aquila and 2016-2017 Norcia-Amatrice [104]). Finally, the first proposal to compare chemical data collected from environmental agencies to observe hydrochemical anomalies was made by Martinelli et al. [105].

\subsection{Mechanisms Proposed for Earthquake-Related Responses}

The mechanisms proposed to explain hydrological and chemical responses observed in previous studies can principally be classified into two main groups: 
- mechanisms originating external to the aquifer, including the intrusion of water from a different source;

- mechanisms internal to the aquifer dynamics, with changes in water-rock interaction.

Mechanisms of the first group include expulsion of water from compressed aquifers [106], aquifer breaching and fluid mixing [14,21,107], interactions with deep fluids or gases [96,101], and consolidation and liquefaction of sediment [108]. Mechanisms of the second group are opening of deep fractures, which can increase chemical release with freshly created rock surface [3] and/or changes groundwater flow and aquifer properties to increase permeability $[2,90,109]$.

A fundamental role in the understanding of the main mechanism at play is knowing the timing and the duration of the response, which gives clear information to discriminate mechanisms, that is, mechanisms immediately correlated with the seismic momentum increase (i.e., the microfracture opening or aquifer breaching) show a fast response after the mainshock [2,73]; mechanisms correlated with increased stress buildup can show anomalies also before the mainshocks, in the preparatory phase [97]. Additionally, the duration of the anomaly could give valuable information to discriminate the main mechanism causing changes (Table 1).

Table 1. Mechanisms causing changes, reporting the chemical variables affected, the expected timing of response, and the studies reporting the changes in Italy.

\begin{tabular}{|c|c|c|c|c|}
\hline Mechanism & Source of Mechanism & Variables Affected & Timing of Response & Observations in Italy \\
\hline Dilation and shaking & Internal & Major and trace elements & $\begin{array}{l}\text { Fast and transient, } \\
\text { post-earthquake }\end{array}$ & {$[2,90,91]$} \\
\hline Aquifer breaching and mixing & External & $\begin{array}{l}\text { Physicochemical parameters; } \\
\text { water isotopes }\end{array}$ & $\begin{array}{l}\text { Post-earthquake with } \\
\text { possible permanent effect }\end{array}$ & {$[88,89]$} \\
\hline Release of deep-seated gases & External & $\begin{array}{c}\text { Dissolved gases; } \\
\text { trace elements }\end{array}$ & $\begin{array}{l}\text { Slow and transient, } \\
\text { observed also } \\
\text { pre-earthquake }\end{array}$ & {$[50,103,110]$} \\
\hline
\end{tabular}

\subsubsection{Degassing and Interaction with Deep Fluids}

Crustal degassing is observed to be strictly correlated with seismic and volcanic activity $[95,111]$. The gases dissolved in groundwater provide information on the water-gas interactions between water containing a dissolved atmospheric component and a deep-seated gas phase that occurs in the subsurface hydrologic system [11]. Among the analyzed gases, $\mathrm{CO}_{2}$ is the main residual component of deep sourced gases, when temperatures drop and the water vapor condenses, and is the most common gas released from colder systems over tectonically active areas. $\mathrm{CO}_{2}$ thus plays an important role for understanding the mechanism, especially for its presence in the aquifers of the Apennines, derived either from deep sources, or from carbonate rock dissolution in the aquifer enhanced through earthquake processes [112]. These separate sources of $\mathrm{CO}_{2}$ can be distinguished by their different carbon isotope signatures, and can play a fundamental role in identifying internal and external mechanisms at play [2].

Along with the major gas components, changes of minor and trace gases (e.g., $\mathrm{He}, \mathrm{Rn}, \mathrm{Ar}$ ) as well as their isotopic fractions (e.g., ${ }^{3} \mathrm{He} /{ }^{4} \mathrm{He}$ ), can be used to evaluate mantle or crustal sources of the observed hydrogeochemical anomalies $[81,83]$. These gases, in fact, originate from the natural radioactive decay of elements in the mantle and crust (mostly $U$ and Th series elements $[84,113]$ ). Therefore, their abrupt change, compared to the baseline atmospheric-derived values, is interpreted as an index of the influence of deeply-derived fluids on groundwater. This suggests that the increase in permeability of rock masses before, during, or after shocks can enhance the interaction of these gases with groundwater [57]. Moreover, minor and trace gases, especially Rn, were widely tested as possible precursory signals for earthquake forecasting $[17,113,114]$.

Degassing can also affect changes in other variables through chemical reactions. $\mathrm{CO}_{2}$, for example, can mobilize redox sensitive metals from oxy-hydroxide phases, causing an increase in their 
concentration in the preparatory phase or after the mainshocks. This mechanism was inferred for trace element increase in groundwaters during the 2009 L'Aquila and 2016-2017 Amatrice sequences [2,96,97]. The effect of interaction or uprising of deep fluids could also directly affect chemical features of waters, typically causing the increase of dissolved trace metals (i.e., $\mathrm{Li}, \mathrm{B}, \mathrm{As}, \mathrm{U}$ ) [101]. This kind of $\mathrm{CO}_{2}$-driven mechanism could manifest itself in differential response timing. Generally, degassing could give a fast response due to the higher mobility of gases, whereas the mechanism involving deep thermal fluids should give a slower response.

\subsubsection{Aquifer Breaching and Mixing}

Seismic waves may enhance the permeability of the affected aquifers through increasing fracture porosity, changing pore pressure, and fracturing aquitards. These seismic effects could result in the mixing of fluids from different aquifers or the upwelling of deep fluids $[109,115,116]$. This effect was observed in various aquifers worldwide [14,107], but was proposed in only few cases in the Apennines (e.g., Piedmont area in the north [88,89]). In the case of aquifer breaching and mixing, timing of response can be faster than other mechanisms (e.g., release of deep-seated fluids), and the duration of the anomaly can be long (on the order of years) or even permanent. Hydrochemical variables that might be expected to change include the composition and concentrations of major ions, as well as water isotopes $[107,115]$.

\subsubsection{Mechanisms Internal to the Aquifer}

The release of seismic energy can generate an increased dilation of existing fractures in the host rock, as well as in the creation of new fractures, which can serve to enhance permeability. This is especially the case in the high flow aquifers in central Italy (which are mostly karst). Seismicity increases permeability with the opening of new micro-fractures, the interconnection of pre-existing cracks and porosity (e.g., isolated pores in travertine), and the removal of infilling from cracks [2,7,70,90]. Evidence of increased permeability is increased flow rates observed after the seismic event, especially when there is no evidence of aquifer breaching described above (no change in major ions nor water isotopes) [90,117].

Moreover, the creation of new micro-fractures can easily expose fresh unweathered rock to the water flow, which can increase the release of major ions through increased water-rock interaction [3]. Another mechanism that is proposed, especially regarding karst springs, is the effect of fracture clearing, i.e., the release of highly mineralized pore water, which had been trapped in fractures and pores. Karst aquifers characteristically have multiple circulation paths (fast flow circuits on the scale of decades travelling along fractures and discontinuities, and much slower flow paths where water travels via seepage through lower permeability pore and fracture networks) [2,24]. Shaking would serve to expel the highly mineralized pore water from the slower circuit into fast flow circuit [2,91].

These internal changes are strongly affected by aquifer hydrogeological features (e.g., recharge area, flow rates and flow circuits, and bedrock geochemistry), which mainly affect the timing and the magnitude of responses. Chemical components (i.e., major and trace elements) derived from within the aquifer system can show anomalies in the form of transient increases in concentration, but variables that indicate water mixing or interaction with deep fluids (e.g., water isotopes, dissolved gases, trace elements associated with deep fluids) are not expected to show changes.

\section{Meta-Analysis: Methods}

While the array of case studies discussed previously report hydrogeochemical changes related to seismicity, a synthesis and analysis of all these published data are missing in literature. Through the methods described in the following paragraphs, we attempted to combine the findings of previous studies to search for similar responses among the seismic sequences reported in the study area. We then inferred the most reliable mechanism to explain the responses. 


\subsection{Data Collection}

Data were collected from published studies that took place during the last 4 major seismic sequences in the Apennines (1997 Colfiorito, 2009 L'Aquila, 2012 Emilia and 2016-2017 Amatrice) from tables, graphs, and supplementary material. For most of the studies, data were not available in electronic format as supplementary material, especially for the oldest papers. Therefore, data were collected manually from tables, where present, and from graphs using data extraction tools (e.g., WebPlotDigitizer, [118]).

We selected the studies containing at least 5 samples collected during the seismic sequence and in the pre- or post- earthquake period, in order to have a significant baseline value for the comparison with anomalies. Data collected only once from springs, without time trends were not included in the statistical analysis, nor were data reported only as mean values \pm standard deviation of preand post- seismic sequences. As well, studies monitoring a single variable for long-term trends (e.g., long term continuous monitoring of $U$ [96]), were not included in the multivariate statistical analysis, since they only increased the noise and complicated data interpretation. All of the remaining studies fitting these criteria were evaluated to determine the most plausible mechanisms explaining chemical changes.

\subsection{Data Processing}

Data were first organized by the spring locality sampled and earthquake sequence monitored. A few studies analyzed the same springs on different dates (and different sequences). In these cases, the times series were merged to observe possible differences in measurements from the different authors and to extend the available time span of monitored data. After the data were organized, all the records were normalized in order to emphasize the anomalies along the time series of data collected, as well as to remove differences in signals due to the high heterogeneity of the different sampling sites (i.e., differently mineralized waters). To accomplish this, a z score normalization of data was calculated following the equation (1):

$$
\mathrm{z}=(\mathrm{x}-\mathrm{m}) / \mathrm{s}
$$

where $z$ is the calculated score, $x$ is the observed value, $m$ is the mean of the whole sampling period and $\mathrm{s}$ is the standard deviation. This normalization easily allowed for the observation of anomalous values and outliers, reducing differences derived from different measuring units and different ranges of variance $[119,120]$. This calculation was performed for every spring selected in the meta-analysis to highlight the anomalies observed in comparison to what were considered background hydrogeochemical values $[120,121]$, including main seasonal trends of each analyzed spring (Figure 5). Normalized values for all the analyzed data were reported in Table S1, supplementary material.

A Principal Component Analysis (PCA) was applied to the dataset, selecting the most frequently analyzed variables in the selected studies to observe their correlations in responses. PCA is a multivariate statistical technique that, through a linear combination of the analyzed variables, generates new uncorrelated variables named principal components. This approach allows observations of the data along the maximum variance of the system. In this way, the correlation of the measured variables (i.e., loadings) could be projected on the spaces defined by the principal components. The data obtained in the different samples can be projected as scores [122-124]. 


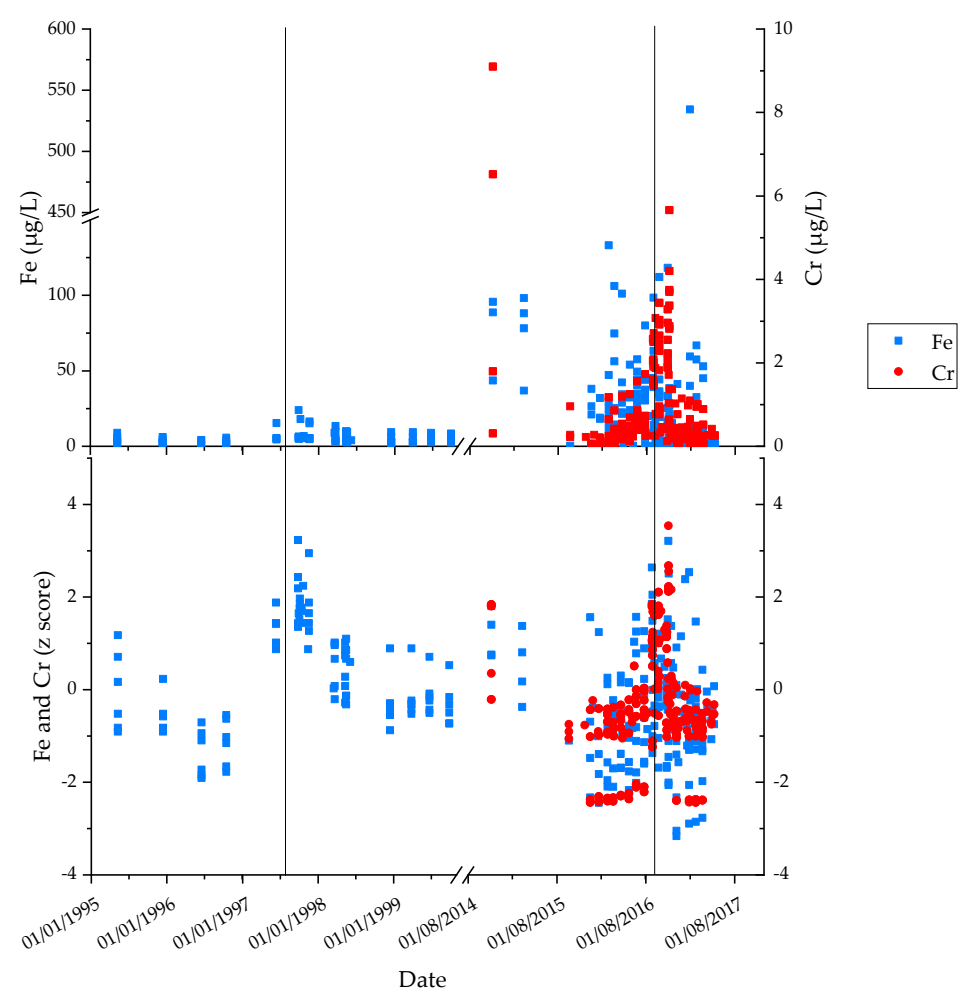

Figure 5. Time trend (dates indicated as $\mathrm{dd} / \mathrm{mm} / \mathrm{yyyy}$ ) of the absolute values (in $\mu \mathrm{g} / \mathrm{L}$ ) and of the $\mathrm{z}$ score of the variables Fe and $\mathrm{Cr}$ during the Colfiorito [87] and Amatrice sequence [2,101]. Black lines indicate the mainshocks of the two sequences (see Section 2.4). In this case, the effects of z-score transformation are observable, especially when analyzing the iron anomaly during the Colfiorito sequence, which is not very evident when analyzing the absolute values.

\section{Statistical Meta-Analysis: Results}

Following the selection criteria described in the methods section, the springs/wells with long time series were selected, as well as the most commonly measured variables in the different studies. Among the literature analyzed, 1771 raw data records were collected for 63 sampling points, reported in 17 published papers.

These studies reported different suites of analyzed variables, which were not well distributed among the springs nor seismic sequences; in fact, different case studies reported different sets of variables. Consequently, we present several different outputs aiming to reveal the main correlations among variables and their response timing, as well as the interpretation of local effects and of tectonic features in the different earthquake sequences.

The normalization of data through z-scores was applied for every spring analyzed and highlights the anomalous values for each variable, compared with the geochemical background of different springs. For example, as observed for $\mathrm{Fe}$ and $\mathrm{Cr}$ (Figure 5), the anomaly reported during the Colfiorito sequence is more easily observable.

\subsection{Variables Showing Changes and Their Correlation}

As mentioned previously, Principal Component Analysis was applied to all the data records collected for the meta-analysis, but some variables (e.g., trace metals and radon) were removed because they were present in too few samples compared to the total number of collected data. Therefore, only physicochemical features, major ions $\left(\mathrm{Ca}, \mathrm{Mg}, \mathrm{Na}, \mathrm{K}, \mathrm{SO}_{4}, \mathrm{HCO}_{3}, \mathrm{Cl}\right)$, dissolved gases $\left(\mathrm{He}, \mathrm{CO}_{2}, \mathrm{CH}_{4}\right.$, $\mathrm{O}_{2}, \mathrm{~N}_{2}$ ), and water isotopes were used for this analysis. Analyzing the loading plots of the PCA (Figure 6A,B) shows which anomalies correlate in the different seismic sequences. The first three components were analyzed in more detail, because they explain about the $70 \%$ of the total variance of 
the system. Component 1 of the PCA, representing one third of the variance, shows a strong separation of most of the cations from the physicochemical parameters along axis 1 . The water isotopes correlate with most of the cations along axis 1, suggesting a partial relationship with aquifers containing specific source waters and all cations but $\mathrm{Ca}$. Moreover, the water isotopes correlate with $\mathrm{CO}_{2}$ and $\mathrm{He}$, suggesting a possible role of gases in the chemical anomalies. There is also a correlation of most of the physicochemical parameters with the anions $\mathrm{Cl}$ and $\mathrm{SO}_{4}$ (Figure 6A,B), elements that are found in highest concentrations within Mesozoic evaporites at depth, indicating a possible release of these elements from evaporites during a seismic event. Dissolved carbonate and dissolved $\mathrm{CO}_{2}$ correlate well with the water isotopes with respect to components 1 and 2 (Figure 6A), suggesting that these properties are associated with processes affecting aquifers with specific source waters. In this way, component 1 is interpreted to indicate the effect of mixing with other water (for the negative values of water isotopes and some gases, which are inversely correlated to main physicochemical parameters), whereas component 2 indicates the role of increased ion concentrations derived from shaking (with high positive values of most of the cations). A plot of the loadings for the first and third components (Figure 6B) shows a strong correlation of $\mathrm{Ca}$ and sulfates and may indicate a stronger influence with evaporitic rocks or brines in some aquifer settings. Moreover, the $\mathrm{CO}_{2}$ and alkalinity results separate differently from principal components 1 and 2 . Therefore, component 3 can explain the anomalies derived from deep fluid and gases, with positive values for $\mathrm{CO}_{2}, \mathrm{He}$, and temperature. Still, this interpretation is limited by the fact that only some variables have sufficient data to allow for multivariate analysis.

A

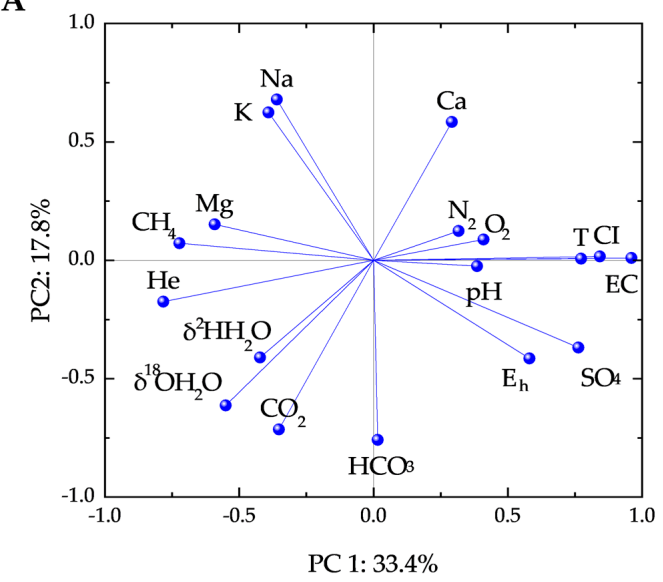

B

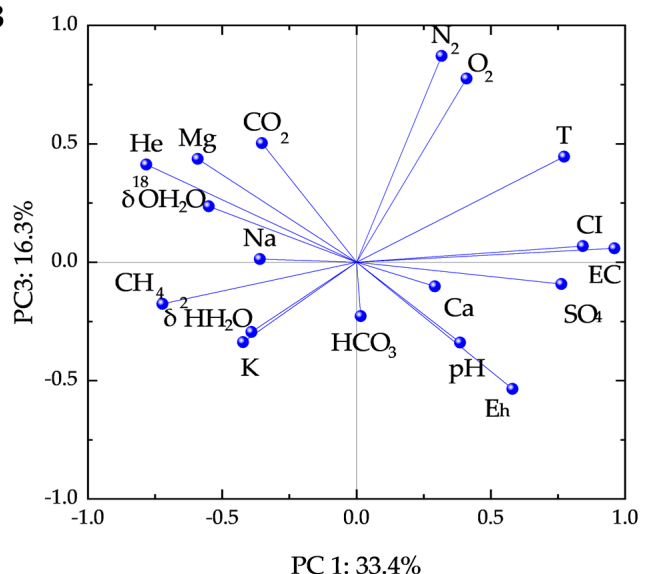

Figure 6. Lading plot of principal component (PC)1 and 2 (A) and of component 1 and 3 (B). Percentage on the axes indicate the explained variance of the system for every principal component. 


\subsection{Effect of Timing and Distance}

Timing of anomalies and the distance of the springs where they are observed from the epicenters are often used to obtain information regarding the mechanism of hydrogeochemical responses [7,125]. Since most of the studies in this meta-analysis report an anomalous increase in solute during seismic sequences, Figure 7A reports the number of variables with $\mathrm{z}$ values greater than 2 and 3 , compared with the number of days before/after the mainshocks (in order to align time series of the different earthquake sequences analyzed). As observed, there is a higher incidence of anomalous values closer to the mainshocks: most of the anomalous values reported (with $\mathrm{z}$ value higher than 3) occur less than 400 days following the mainshock and about half of the anomalies observed in the studies analyzed are reported during the 6 months following the first mainshock. This is the period mostly affected by major aftershocks in the last seismic sequences. These data highlight the effect of timing in defining the possible mechanisms because most of the anomalies are observable during a short period following the main shock, whereas a few other anomalies seem to happen after a long period.

The long-term anomalies are difficult to attribute to a particular factor and may be related to other features (e.g., climate). In addition, there are some springs which showed no anomalies. These features indicate that timing can be a helpful tool in defining anomalies but still need to be validated with other markers. Notably, there are more variables showing anomalies after the mainshocks than before, but this observation may be biased by the higher number of samples collected immediately after mainshocks, compared to before. Different springs are, in fact, analyzed with high sampling frequency only after mainshocks.

Comparing the anomalous values observed and the distances of sampling points from the epicenters of the mainshocks, which is often used to try to understand the effects of seismic energy release for groundwater changes [125], there is no clearly observable trend. Roughly about half of the anomalous values were observed less than $20 \mathrm{~km}$ from the epicenter of the mainshock, but other anomalies were observed farther than $80 \mathrm{~km}$ (Figure 7B). This lack of correlation could reflect the fact that response is more affected by the hydrogeological features of the aquifer, such as the recharge area and the bedrock geochemistry, than by distance. Therefore, in this setting the distance from epicentral area seems to show little correlation to the hydrochemical response. Nonetheless, in the case of this meta-analysis, the maximum distance of sampling points was limited to $<100 \mathrm{~km}$, but a few studies reported in this review (e.g., [25]) report anomalies at even higher distances. It should also be noted that when considering all the recent earthquake sequences in the Apennines, other mainshocks happened within $40 \mathrm{~km}$ from the epicenter of the first shock, possibly affecting these results (Figure 7B).

The analysis of different hypocenters was not reported here because the differences in this value among the sequences were generally less than 2 kilometers (most of the mainshocks were in the range $8-10 \mathrm{~km}$ below ground surface [32,61,64,67]).

As a side note, there is a relatively high number of $Z$ values $>3$ during all seismic sequences, highlighting the fact that the geochemical anomalies related to earthquakes mostly cause a high change of chemical variables compared with the geochemical background of the analyzed aquifer. 
A

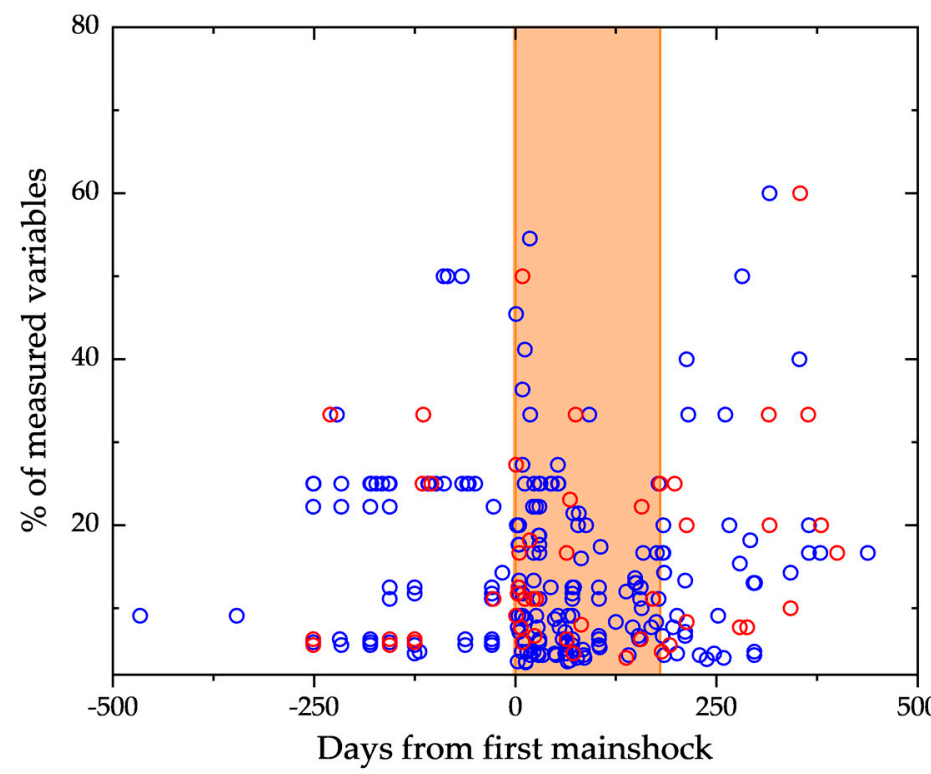

B

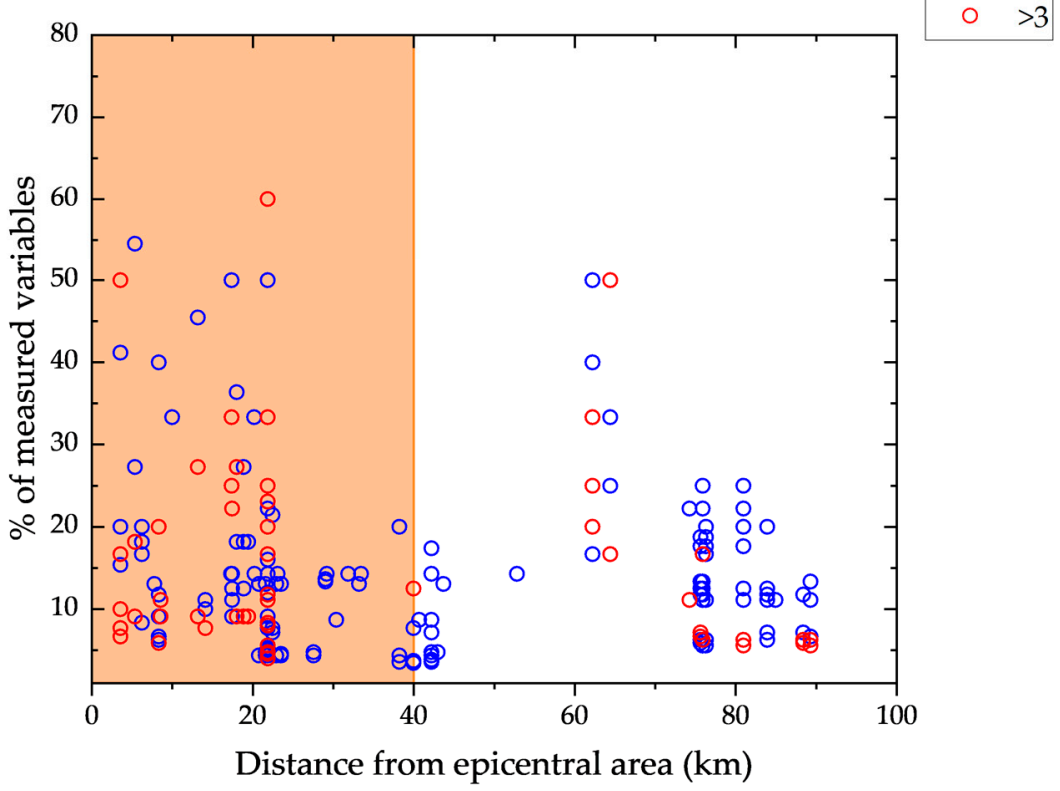

Figure 7. Number of variables showing anomalies observed in the studies (expressed as the percentage with respect to the whole dataset analyzed) compared to: (A) the time span from the occurrence of the mainshock (orange shaded area indicates the time delay of other shocks with Mw $>4.5$ after the mainshock); (B) the distance from the epicenter of the mainshock (the orange shaded area indicates the maximum distance of other mainshocks, in order to highlight the springs sampled in the epicentral areas).

\section{Understanding the Main Mechanisms Causing Anomalies}

The most promising and representative mechanism to explain the observed changes in the discussed data will be proposed in the following section, focusing on the chemical variables and the hydrogeological features that are most important in the investigation of hydrogeochemical responses. In this section, the meta-analysis of available data is merged with the interpretations proposed in the literature to explain the geochemical anomalies observed in the Apennines (also in the studies which could not be included in the meta-analysis), in order to infer the most plausible mechanisms at play. 


\subsection{The Focal Role of Hydrogeological Setting in Defining the Mechanism}

The collection and analysis of different case studies allows us to highlight the most plausible and frequently occurring mechanisms for earthquake-related anomalies in the Apennines. The observed responses vary widely depending on water flow and the hydrologic and geologic setting of the recharge areas, whereas distance from epicentral area seems to be have little influence (Figure 7B). This evidence confirms that the main hydrogeological features of the analyzed aquifer and the geochemical background levels need to be well known in order to understand the most plausible mechanism that leads to hydrochemical anomalies.

In thermal springs, which have a higher heat flux, the water chemistry is highly influenced by its gas component. It is also expected that these springs could have a higher interaction with deep fluids or gases (i.e., $\mathrm{CO}_{2}, \mathrm{H}_{2} \mathrm{~S}$ ), which could affect redox phenomena and dissolution patterns [12,101,126]. In fact, these springs (such as the springs analyzed during 1996 Colfiorito sequence [11]) showed changes in dissolved gas composition, as well as in their isotopic ratios (e.g., ${ }^{3} \mathrm{He} /{ }^{4} \mathrm{He}$ ), as an indication of higher interaction with deep fluids [11,93]. These thermal-spring settings, in fact, seem more frequently influenced by mechanisms external to the aquifer during seismic crisis. Moreover, these anomalies can cause a fast response after the earthquake shock, as reported in our meta-analysis (Figure 7A).

As observed in various studies of the four most recent seismic sequences, as well as from the PCA loading plot of our meta-analysis, $\mathrm{CO}_{2}$ and carbonate equilibria play an important role in the hydrochemistry of the Apennines. Analysis of the plots of PCA loadings in Figure 6A,B indicates that they are, in fact, well correlated observing principal component 2, indicating an effect internal to the aquifer (Figure 6A). However, these variables are not correlated (see principal component 3 ) (Figure 6B), which could possibly indicate a different source of $\mathrm{CO}_{2}$ from deep fluids (these results correlate with $\mathrm{He}$, another deep sourced gas). In the PCA loading plot, $\mathrm{CO}_{2}$ concentrations correlate with isotopes of water both on components 2 and 3 . This correlation can indicate a mixing of other water sources correlated with changes in permeability after the release of seismic energy $[6,109]$ as an explanation of the increase in dissolved $\mathrm{CO}_{2}$. These findings indicate that $\mathrm{CO}_{2}$ can be a driver of groundwater changes correlated with seismicity, especially for springs with high heat flux (e.g., thermal hot springs) $[65,95]$. $\mathrm{CO}_{2}$, moreover, plays an important role in the interaction with other chemicals affecting water quality; this gas, in fact, could enhance the dissolution of redox-sensitive metals in water, an effect already proposed in some case studies $[2,12,96]$, which could affect even cold shallow springs after the degassing caused by increased permeability during seismic activity $[87,102]$. It seems clear that deep-seated gas release is strongly affecting the chemistry of water in central Italy and this mechanism could be a valid hypothesis to explain the observed anomalies [12].

Shallower cold springs (karst or alluvial), on the other hand, mainly showed responses in major ions, as well as in trace elements, which generally show sharp changes in their concentration caused by mixing with stagnant fluids or release of elements from poorly bound exchange sites (e.g., Figure 5). This mechanism explains the fast response of the springs after the mainshock observed in our meta-analysis (Figure 7A). In the case of karst and alluvial aquifers, moreover, the interaction with deep fluids is less likely to happen because of the thickness of low-permeability sediment strata of shallow recharge areas. The mechanism playing an important role in the setting of karst and alluvial aquifers (typical of the studied area) is the increase in permeability following the release of seismic energy, which causes the effect of fracture cleaning, as well as new exposure of fresh unweathered rock and the release of pore water into the fast flow circuit typical of these aquifers [2,26]. In this case the observed anomalies include a transient increase in the concentration of major ions and trace elements, which was observed widely during the last historical seismic sequences in the Apennines $[2,90,91]$. As observed in the PCA loading plot of components 1 and 3 (Figure 6B), the increase of ions derived from dissolution of gypsum and brines (e.g., $\mathrm{Cl}$ and $\mathrm{SO}_{4}$, well correlated with $\mathrm{EC}$ in Figure 6) is the main chemical change indicating this type of anomaly, especially for the karst aquifers, presenting higher thickness and a possible enrichment in $\mathrm{SO}_{4}$ and $\mathrm{Cl}$ (Figure 3, [2,58]). Moreover, in more recent studies (e.g., [2]), even trace element increases are reported as a proxy of this type of mechanism. 
Following these hypotheses, variables such as dissolved gases and their isotopic ratio, major ions generally dissolving in karst aquifers, and trace metals are among the most reliable variables to evaluate the mechanisms causing changes in water chemistry. Trace metals were mostly analyzed in more recent studies but revealed important trends that were used to understand the mechanisms of hydrogeochemical anomalies and are of increasing interest in this research field $[2,20,127]$.

\subsection{Tectonic Setting and Hydrochemical Response}

When evaluating the role of tectonic setting on hydrochemical responses, we saw common features, regardless of the setting. The tectonic setting of the central Apennines is associated with a dip-slip focal mechanism of earthquake formation, which should result in dilation. In the northern area, the focal mechanism causing earthquakes is associated with a strike slip setting, presenting less dilation (and consequently possible lower degassing and slightly increased permeability). The major changes observed during the 2012 Emilia earthquake (in the northern Apennines) are similar to the responses of the seismic sequences in the central Apennines: anomalous increase of dissolved gases especially in deep wells [65], presumably derived from deep-seated fluid interaction, and a slight increase in major ions observed in shallower karst aquifers [99]. The results in the 2012 Emilia earthquake are similar to anomalies observed in other localities with this tectonic setting, such as the increase of dissolved gases during the Colfiorito sequence [57], and the increase in major ions observed in shallower springs observed during Colfiorito, L'Aquila and Amatrice sequences [2,74,87].

While some authors indicated that earthquake-related chemical parameters can give us information to detect the focal mechanisms causing these responses $[125,128]$, the results of this meta-analysis do not support that view. The 2012 Emilia sequence is the only one analyzed in this meta-analysis with a stike-slip focal mechanism, offering limited evidence to ensure a lack of differences.

While the direct effect of earthquake focal mechanisms on the hydrogeochemical responses to seismicity is not elucidated in this study, the hydrogeological setting is inevitably affected by the tectonic one. In this way, the different tectonic (and hydrogeologic) settings can present different types of responses to seismicity. For example, the high variability in $\mathrm{CO}_{2}$ degassing sources changes with the setting $[95,104,129]$. During the last seismic sequences, the analysis of springs that have a large recharge area and can be affected by a deep source of $\mathrm{CO}_{2}$ (typical of the Tyrrhenian domain) showed an evident increase in metal concentrations as well as fractionation of $\delta^{13} \mathrm{C}$ isotopes, indicating gas exchange from the deep $\mathrm{CO}_{2}$ source $[2,12,93,98,101,110]$. Alternatively, aquifers that are mainly fed by shallow groundwater in the karst system (mainly present in the Adriatic domain) showed chemical changes caused directly by the increase in permeability and fracturing after the shock $[2,90,101]$.

\section{Knowledge Gaps and Future Perspectives for Earthquake Monitoring}

Earthquakes are sudden, seemingly random events that make it difficult to collect long-term data for analysis that can be used to understand a complete picture of the pre- and post- shock responses. This is the main reason for the present situation, where a multitude of reported case studies have different unsolved issues regarding their nature (e.g., the role of pre-seismic anomalies, the length of the anomaly, or the heterogeneity in response among springs). In this section, the future trends for hydrogeochemical response analysis will be proposed, and the still debated issues of this discipline will be discussed.

\subsection{Geochemical Precursors: A Research Horizon or A False Claim?}

Earthquake forecasting is an attractive pursuit in the geological sciences that has been of interest since the early 1960s (Weichiuan earthquake), and this topic is still attracting considerable interest and generating contrasting opinions among the experts in this field $[77,113,130]$.

Despite efforts to locate universal and reliable precursors, these signals are, at best, inconsistent and unreliable, because they do not always occur in the same places preceding major seismic events, do not always occur consistently within strongly affected areas (e.g., [2]), and can be generated from 
different mechanisms, making it difficult to find a systematic and reliable marker. Therefore, skepticism is high in the scientific community that reliable geochemical precursors can be determined [131,132]. Nonetheless, precursor signals are an area of research that has received considerable interest because of the potential benefit they could bring in disaster management $[130,133]$.

During the period analyzed in this review, evidence of possible earthquake precursors was proposed in a few studies in central Italy. Precursory effects in U concentration were observed before the 2009 L'Aquila mainshock in the preparatory phase [96], and the authors of the study suggested that this element can be used as a potential indicator of pre-earthquake processes. In another study, an anomalous increase in a few trace metals was observed the month before the 2016-2017 Amatrice earthquake mainshock [101]. Also, an anomalous peak in carbon derived from a deep source was observed in a series of springs before the 2009 L'Aquila mainshock [103].

Analysis of the data collected in this review shows that pre-earthquake anomalies reported are fairly limited when compared with the observation of post-seismic effects. There is a sampling bias that makes pre-earthquake anomalies hard to evaluate, since the majority of observations occur after the seismic event has occurred. Consequently, this area of research needs further study and analysis in order to have more application, thus requiring a more robust pre-earthquake time series, including additional long-term discrete chemical data and potentially continuous data from a greater number of wells and springs. Such data may be able to shed light on the mechanisms that drive the changes, with the potential to use them as possible proxies of the preparatory pre-earthquake phase.

\subsection{The Drawback of Data Availability and Data Analysis}

The sporadic sampling of hydrochemical responses to seismic activity, mainly due to the lack of consistent and coordinated data collection, is one of the main obstacles preventing improved understanding of the mechanisms of earthquake induced anomalies. The length of the time series available and the quantification of background concentrations of elements are fundamental to avoid misleading results (e.g., false anomalies). The comparison with climate data (precipitation and temperature), flow data, and the observation of normal seasonal trends in chemical variables may be helpful in understanding how other mechanisms (e.g., aquifer breaching, deep seated fluid interaction) are changing water chemistry. In this way, harmonized and complete datasets are needed for a clear comprehension of these complex mechanisms.

As observed in this meta-analysis, multivariate statistical methods give valuable information about signal anomalies observed in data analysis, and data reduction techniques permit an understanding of which variables are causing the anomalies $[2,3,56,134,135]$, as well as showing the timing during which variables are changing, which may elucidate mechanisms at play. In this review, seasonal cyclic changes and noise were removed using statistical tools (especially for long term monitoring with probes [92,100]). However, in some studies (e.g., [90,91]), average values of pre and post seismic data were used without considering the time span used for calculating the average. This kind of approach can complicate data interpretation, especially in areas that have marked seasonal trends, because the annual variance of data could blur the signal of the hydrogeochemical anomaly.

Moreover, while not deeply analyzed in this meta-analysis, continuous monitoring of physicochemical parameters could be helpful to observe the timing of responses with a high resolution (e.g., [41,136,137]). Nonetheless, the limited number of variables that could be monitored can lead to overlooking certain anomalies that may show up in snapshot sampling of a wider array of variables. A preliminary selection of chemical variables to monitor, based on the anomalies observed in the past, would be helpful and should ideally involve periodic samples of water isotopes, dissolved gasses, and selected ion chemistry

\subsection{Towards Coordinated Data Collection to Clarify Mechanisms at Play}

As observed in this review, consistent data harmonization can help to understand the main drivers causing hydrogeochemical anomalies related to seismicity; in fact, correlating similarities 
among different sporadic case studies helped identify coherent trends explaining the main mechanisms causing anomalies. Nonetheless, a joint and coordinated long-term data collection network would improve understand these phenomena [138].

The central Apennines, with an active recent history of earthquake sequences and a great number of regional aquifers providing public water supply is a plausible study area to set up a coordinated hydrochemical monitoring network. Additionally, given that our meta-analysis involved only 1 sequence from the Adriatic Domain, additional data from this tectonic setting could be helpful in ascertaining the role of focal mechanisms and stress regimes on hydrogeochemical response. With regards to the practicality of this endeavor, the monitoring of water chemical parameters is already in practice throughout the region, due to water standards monitoring in bottling plants, as well as thermal water plants, which were already analyzed during seismic sequences (e.g., $[2,11,99])$, providing a head start in establishing such a sampling network. Within the historical window that includes the studies in this review, the idea of a monitoring system was proposed in several articles and feasibility studies were reported $[137,139,140]$, but a coordinated, long-term monitoring system has yet to be established. Recently, a preliminary group of research institutes started a collaboration with regional environmental agencies to set up a national monitoring system of hydrogeochemical variables connected with geological hazard observations [141], and if established, this monitoring network will be of great benefit in this endeavor, taking advantage of the water quality monitoring infrastructure already in place for bottling plants.

\section{Conclusions}

In this review, the Apennines of central Italy was chosen as a field laboratory to understand changes in water chemistry in response to seismicity, due to the high frequency of earthquakes and the high number of case studies reporting chemical anomalies. Following a meta-analysis based on studies from the last five historical seismic sequences in this region, the main variables showing changes were revealed.

The important role of response timing and duration was highlighted to elucidate the mechanisms causing changes. A differential response was often observed between the type of aquifers analyzed. Natural background values of springs are invaluable in determining hydrochemical response to seismicity and must capture natural variation, including seasonality, to avoid misinterpreting results. Interestingly, there was a common hydrochemical response that transgressed both distance of earthquakes from monitoring sites, as well as the focal mechanism of earthquake sequences and the tectonic setting at the spring site.

Two factors appear to play an important role in karst aquifers in this region; deep $\mathrm{CO}_{2}$ release and changes in permeability, which has led to the hypothesis that two main mechanisms show hydrogeochemical anomalies: the release of deep gases derived external to the aquifer and the enhancement in permeability and fracturing due to earthquake shaking. These two mechanisms explain the different responses observed in different springs types, correlated also with the different hydrogeological settings of the areas. Nonetheless, open questions remain unsolved after these observations. Why are the anomalies generally not well distributed, with differences in responses? Could we obtain specific responses also from pre-earthquake data? A more complete understanding of mechanisms causing anomalies may come with a more complete, long-term dataset with harmonized data, in part generated by coordinated monitoring efforts. The creation of a monitoring network for data collection and analysis for the Apennines would significantly further our understanding of the relationships between seismic events and hydrogeochemical responses in aquifers.

Supplementary Materials: The following are available online at http://www.mdpi.com/2075-163X/10/12/1058/s1, Table S1: z scores of all measures used for meta-analysis.

Author Contributions: Conceptualization, G.B.; methodology, G.B. and A.P.; data curation, G.B.; writing-original draft preparation, G.B.; writing—review and editing, P.J.N., M.R.R., A.M.M. and A.P.; funding acquisition, P.J.N., M.R.R. All authors have read and agreed to the published version of the manuscript. 
Funding: This work was funded by a RAPID supplement to the National Science Foundation grant GSS-1228126 requested by Paula Noble and Michael Rosen and a University of Insubria grant for the 2016-2017 central Italy seismic sequence requested by Franz Livio.

Acknowledgments: Authors wish to thank the three anonymous reviewers and William C Evans for their helpful comments, highly improving the manuscript quality. Any use of trade, firm, or product names is for descriptive purposes only and does not imply endorsement by the U.S. Government.

Conflicts of Interest: The authors declare no conflict of interest.

\section{References}

1. Grant, R.A.; Halliday, T.; Balderer, W.P.; Leuenberger, F.; Newcomer, M.; Cyr, G.; Freund, F.T. Ground Water Chemistry Changes before Major Earthquakes and Possible Effects on Animals. Int. J. Environ. Res. Public Health 2011, 8, 1936-1956. [CrossRef]

2. Rosen, M.R.; Binda, G.; Archer, C.; Pozzi, A.; Michetti, A.M.; Noble, P.J. Mechanisms of earthquake induced chemical and fluid transport to carbonate groundwater springs after earthquakes. Water Resour. Res. 2018, 54, 5225-5244. [CrossRef]

3. Skelton, A.; Andrén, M.; Kristmannsdóttir, H.; Stockmann, G.; Mörth, C.-M.; Sveinbjörnsdóttir, Á.; Jónsson, S.; Sturkell, E.; Guðrúnardóttir, H.R.; Hjartarson, H.; et al. Changes in groundwater chemistry before two consecutive earthquakes in Iceland. Nat. Geosci. 2014, 7, 752. [CrossRef]

4. Mohr, C.H.; Manga, M.; Wang, C.; Kirchner, J.W.; Bronstert, A. Shaking water out of soil. Geology 2015, 43, 207-210. [CrossRef]

5. Wang, C.-Y.; Manga, M. New streams and springs after the 2014 Mw6.0 South Napa earthquake. Nat. Commun. 2015, 6, 7597. [CrossRef] [PubMed]

6. Petitta, M.; Mastrorillo, L.; Preziosi, E.; Banzato, F.; Barberio, M.D.; Billi, A.; Cambi, C.; De Luca, G.; Di Carlo, G.; Di Curzio, D.; et al. Water-table and discharge changes associated with the 2016-2017 seismic sequence in Central Italy: Hydrogeological data and a conceptual model for fractured carbonate aquifers. Hydrogeol. J. 2018, 26, 1009-1026. [CrossRef]

7. Wang, C.-Y.; Manga, M. Hydrologic responses to earthquakes and a general metric. Geofluids 2010, 10, $206-216$.

8. Shi, Z.; Wang, G.; Manga, M.; Wang, C.-Y. Continental-scale water-level response to a large earthquake. Geofluids 2015, 15, 310-320. [CrossRef]

9. Sato, T.; Takahashi, H.A.; Kawabata, K.; Takahashi, M.; Inamura, A.; Handa, H. Changes in the nitrate concentration of spring water after the 2016 Kumamoto earthquake. J. Hydrol. 2020, 580, 124310. [CrossRef]

10. Pece, R.; Tranfaglia, G. Hydrological and Geochemical Changes Related to Earthquakes_Examples: Three Great Earthquakes of the XX Century in the Southern Apennines (Italy). In Earthquake Research and Analysis_Seismology, Seismotectonic and Earthquake Geology; InTech: London, UK, 2012.

11. Italiano, F.; Martinelli, G.; Bonfanti, P.; Caracausi, A. Long-term (1997-2007) geochemical monitoring of gases from the Umbria-Marche region. Tectonophysics 2009, 476, 282-296. [CrossRef]

12. Barbieri, M.; Boschetti, T.; Barberio, M.D.D.; Billi, A.; Franchini, S.; Iacumin, P.; Selmo, E.; Petitta, M. Tracing deep fluid source contribution to groundwater in an active seismic area (Central Italy): A combined geothermometric and isotopic ( $813 \mathrm{C}$ ) perspective. J. Hydrol. 2020, 582, 124495. [CrossRef]

13. Manga, M.; Wang, C.-Y. 4.12-Earthquake Hydrology. In Treatise on Geophysics, 2nd ed.; Schubert, G., Ed.; Elsevier: Oxford, UK, 2015; pp. 305-328. ISBN 978-0-444-53803-1.

14. Wang, C.-Y.; Liao, X.; Wang, L.-P.; Wang, C.-H.; Manga, M. Large earthquakes create vertical permeability by breaching aquitards. Water Resour. Res. 2016, 52, 5923-5937. [CrossRef]

15. De Luca, G.; Di Carlo, G.; Tallini, M. A record of changes in the Gran Sasso groundwater before, during and after the 2016 Amatrice earthquake, Central Italy. Sci. Rep. 2018, 8, 15982. [CrossRef] [PubMed]

16. Ulomov, V.; Mavashev, B. A precursor of a strong tectonic earthquake. Dok. Akad. Nauk Sci. USSR 1967, 176, 9-11.

17. Tsunogai, U.; Wakita, H. Precursory chemical changes in ground water: Kobe earthquake, Japan. Science 1995, 269, 61. [CrossRef] [PubMed]

18. Virk, H.S.; Walia, V.; Kumar, N. Helium/radon precursory anomalies of Chamoli earthquake, Garhwal Himalaya, India. J. Geodyn. 2001, 31, 201-210. [CrossRef] 
19. Jin, Z.; West, A.J.; Zhang, F.; An, Z.; Hilton, R.G.; Yu, J.; Wang, J.; Li, G.; Deng, L.; Wang, X. Seismically enhanced solute fluxes in the Yangtze River headwaters following the AD 2008 Wenchuan earthquake. Geology 2016, 44, 47-50. [CrossRef]

20. Shi, Z.; Zhang, H.; Wang, G. Groundwater trace elements change induced by M5.0 earthquake in Yunnan. J. Hydrol. 2020, 581, 124424. [CrossRef]

21. Poitrasson, F.; Dundas, S.H.; Toutain, J.-P.; Munoz, M.; Rigo, A. Earthquake-related elemental and isotopic lead anomaly in a springwater. Earth Planet. Sci. Lett. 1999, 169, 269-276. [CrossRef]

22. Archer, C.; Noble, P.; Rosen, M.R.; Sagnotti, L.; Florindo, F.; Mensing, S.; Piovesan, G.; Michetti, A.M. Lakes as paleoseismic records in a seismically-active, low-relief area (Rieti Basin, Central Italy). Quat. Sci. Rev. 2019, 211, 186-207. [CrossRef]

23. Martinelli, G.; Dadomo, A. Factors constraining the geographic distribution of earthquake geochemical and fluid-related precursors. Chem. Geol. 2017, 469, 176-184. [CrossRef]

24. Amoruso, A.; Crescentini, L.; Petitta, M.; Rusi, S.; Tallini, M. Impact of the 6 April 2009 L'Aquila earthquake on groundwater flow in the Gran Sasso carbonate aquifer, Central Italy. Hydrol. Process. 2011, 25, 1754-1764. [CrossRef]

25. Allegri, L.; Bella, F.; Della Monica, G.; Ermini, A.; Improta, S.; Sgrigna, V.; Biagi, P.F. Radon and tilt anomalies detected before the Irpinia (south Italy) earthquake of November 23, 1980 at great distances from the epicenter. Geophys. Res. Lett. 1983, 10, 269-272. [CrossRef]

26. Skelton, A.; Liljedahl-Claesson, L.; Wästeby, N.; Andrén, M.; Stockmann, G.; Sturkell, E.; Mörth, C.-M.; Stefansson, A.; Tollefsen, E.; Siegmund, H.; et al. Hydrochemical Changes Before and After Earthquakes Based on Long-Term Measurements of Multiple Parameters at Two Sites in Northern Iceland-A Review. J. Geophys. Res. Solid Earth 2019, 124, 2702-2720. [CrossRef]

27. Silverii, F.; D’Agostino, N.; Borsa, A.A.; Calcaterra, S.; Gambino, P.; Giuliani, R.; Mattone, M. Transient crustal deformation from karst aquifers hydrology in the Apennines (Italy). Earth Planet. Sci. Lett. 2019, 506, $23-37$. [CrossRef]

28. Doglioni, C. A proposal for the kinematic modelling of W-dipping subductions-Possible applications to the Tyrrhenian-Apennines system. Terra Nov. 1991, 3, 423-434. [CrossRef]

29. Royden, L.; Patacca, E.; Scandone, P. Segmentation and configuration of subducted lithosphere in Italy: An important control on thrust-belt and foredeep-basin evolution. Geology 1987, 15, 714-717. [CrossRef]

30. Patacca, E.; Sartori, R.; Scandone, P. Tyrrhenian Basin and Apenninic Arcs: Kinematic relations since late Tortonian times. Boll. Soc. Geol. Ital. 1990, 45, 425-451.

31. Carminati, E.; Doglioni, C. Alps vs. Apennines: The paradigm of a tectonically asymmetric Earth. Earth Sci. Rev. 2012, 112, 67-96. [CrossRef]

32. Michetti, A.M.; Giardina, F.; Livio, F.; Mueller, K.; Serva, L.; Sileo, G.; Vittori, E.; Devoti, R.; Riguzzi, F.; Carcano, C.; et al. Active compressional tectonics, quaternary capable faults, and the seismic landscape of the po plain (northern Italy). Ann. Geophys. 2012, 55, 969-1001.

33. Roberts, G.P.; Michetti, A.M. Spatial and temporal variations in growth rates along active normal fault systems: An example from The Lazio-Abruzzo Apennines, Central Italy. J. Struct. Geol. 2004, 26, 339-376. [CrossRef]

34. Galadini, F.; Falcucci, E.; Galli, P.; Giaccio, B.; Gori, S.; Messina, P.; Moro, M.; Saroli, M.; Scardia, G.; Sposato, A. Time intervals to assess active and capable faults for engineering practices in Italy. Eng. Geol. 2012, 139-140, 50-65. [CrossRef]

35. Cello, G.; Mazzoli, S.; Tondi, E.; Turco, E. Active tectonics in the Central Apennines and possible implications for seismic hazard analysis in peninsular Italy. Tectonophysics 1997, 272, 43-68. [CrossRef]

36. Minissale, A.; Vaselli, O. Karst springs as "natural" pluviometers: Constraints on the isotopic composition of rainfall in the Apennines of Central Italy. Appl. Geochem. 2011, 26, 838-852. [CrossRef]

37. Peruccacci, S.; Brunetti, M.T.; Gariano, S.L.; Melillo, M.; Rossi, M.; Guzzetti, F. Rainfall thresholds for possible landslide occurrence in Italy. Geomorphology 2017, 290, 39-57. [CrossRef]

38. Boni, C.; Bono, P.; Capelli, G. Schema idrogeologico dell'Italia centrale. Mem. Soc. Geol. Ital. 1986, 35, 991-1012.

39. Frondini, F. Geochemistry of regional aquifer systems hosted by carbonate-evaporite formations in Umbria and southern Tuscany (Central Italy). Appl. Geochem. 2008, 23, 2091-2104. [CrossRef] 
40. Carminati, E.; Lustrino, M.; Doglioni, C. Geodynamic evolution of the central and western Mediterranean: Tectonics vs. igneous petrology constraints. Tectonophysics 2012, 579, 173-192. [CrossRef]

41. Colangelo, G.; Martinelli, G.; Mucciarelli, M.; Lapenna, V.; Telesca, L. Anomalous pattern of geochemical data recorded in the seismically active site of Pieschi (Southern Italy). Ann. Geophys. 2007, 50, 539-545.

42. Cortecci, G.; Reyes, E.; Berti, G.; Casati, P. Sulfur and oxygen isotopes in Italian marine sulfates of Permian and Triassic ages. Chem. Geol. 1981, 34, 65-79. [CrossRef]

43. Boschetti, T.; Cortecci, G.; Toscani, L.; Iacumin, P. Sulfur and oxygen isotope compositions of Upper Triassic sulfates from northern Apennines (Italy): Paleogeographic and hydrogeochemical implications. Geol. Acta 2011, 9, 129-147.

44. Vignaroli, G.; Faccenna, C.; Jolivet, L.; Piromallo, C.; Rossetti, F. Subduction polarity reversal at the junction between the Western Alps and the Northern Apennines, Italy. Tectonophysics 2008, 450, 34-50. [CrossRef]

45. Doglioni, C.; Mongelli, F.; Pialli, G. Boudinage of the Alpine belt in the Apenninic back-arc. Mem. Soc. Geol. Ital. 1998, 52, 457-468.

46. Critelli, S.; Le Pera, E.; Galluzzo, F.; Milli, S.; Moscatelli, M.; Perrotta, S.; Santantonio, M. Interpreting siliciclastic-carbonate detrital modes in foreland basin systems: An example from Upper Miocene arenites of the central Apennines, Italy. Spec. Pap. Soc. Am. 2007, 420, 107.

47. Patacca, E.; Scandone, P. Post-Tortonian mountain building in the Apennines. The role of the passive sinking of a relic lithospheric slab. In The Lithosphere in Italy: Advances in Earth Science Research; Borianni, A., Ed.; Accademia Nazionale dei Lincei: Rome, Italy, 1989.

48. Cosentino, D.; Cipollari, P.; Marsili, P.; Scrocca, D. Geology of the central Apennines: A regional review. J. Virtual Explor. 2010, 36, 1-37. [CrossRef]

49. Guerrieri, L.; Blumetti, A.M.; Esposito, E.; Michetti, A.M.; Porfido, S.; Serva, L.; Tondi, E.; Vittori, E. Capable faulting, environmental effects and seismic landscape in the area affected by the 1997 Umbria-Marche (Central Italy) seismic sequence. Tectonophysics 2009, 476, 269-281. [CrossRef]

50. Chiodini, G.; Cardellini, C.; Amato, A.; Boschi, E.; Caliro, S.; Frondini, F.; Ventura, G. Carbon dioxide Earth degassing and seismogenesis in Central and Southern Italy. Geophys. Res. Lett. 2004, 31. [CrossRef]

51. Di Luccio, F.; Chiodini, G.; Caliro, S.; Cardellini, C.; Convertito, V.; Pino, N.A.; Tolomei, C.; Ventura, G. Seismic signature of active intrusions in mountain chains. Sci. Adv. 2018, 4, e1701825. [CrossRef]

52. Monaco, C.; Catalano, S.; Cocina, O.; De Guidi, G.; Ferlito, C.; Gresta, S.; Musumeci, C.; Tortorici, L. Tectonic control on the eruptive dynamics at Mt. Etna Volcano (Sicily) during the 2001 and 2002-2003 eruptions. J. Volcanol. Geotherm. Res. 2005, 144, 211-233. [CrossRef]

53. Cinti, D.; Poncia, P.P.; Brusca, L.; Tassi, F.; Quattrocchi, F.; Vaselli, O. Spatial distribution of arsenic, uranium and vanadium in the volcanic-sedimentary aquifers of the Vicano-Cimino Volcanic District (Central Italy). J. Geochem. Explor. 2015, 152, 123-133. [CrossRef]

54. Ciotoli, G.; Guerra, M. Distribution and physico-chemical data of Italian bottled natural mineral waters. J. Maps 2016, 12, 917-935. [CrossRef]

55. Minissale, A. Thermal springs in Italy: Their relation to recent tectonics. Appl. Geochem. 1991, 6, $201-212$. [CrossRef]

56. Quattrocchi, F.; Pik, R.; Pizzino, L.; Guerra, M.; Scarlato, P.; Angelone, M.; Barbieri, M.; Conti, A.; Marty, B.; Sacchi, E.; et al. Geochemical changes at the Bagni di Triponzo thermal spring during the Umbria-Marche 1997-1998 seismic sequence. J. Seismol. 2000, 4, 567-587. [CrossRef]

57. Italiano, F.; Martinelli, G.; Rizzo, A. Geochemical evidence of seismogenic-induced anomalies in the dissolved gases of thermal waters: A case study of Umbria (Central Apennines, Italy) both during and after the 1997-1998 seismic swarm. Geochem. Geophys. Geosystems 2004, 5, Q11001. [CrossRef]

58. Mastrorillo, L.; Petitta, M. Effective infiltration variability in the Umbria-Marche carbonate aquifers of Central Italy. J. Mediterr. Earth Sci. 2010, 2, 9-18.

59. Carucci, V.; Petitta, M.; Aravena, R. Interaction between shallow and deep aquifers in the Tivoli Plain (Central Italy) enhanced by groundwater extraction: A multi-isotope approach and geochemical modeling. Appl. Geochem. 2012, 27, 266-280. [CrossRef]

60. Grassi, S.; Cortecci, G. Hydrogeology and geochemistry of the multilayered confined aquifer of the Pisa plain (Tuscany-Central Italy). Appl. Geochem. 2005, 20, 41-54. [CrossRef]

61. Pantosti, D.; Valensise, G. Faulting mechanism and complexity of the November 23, 1980, Campania-Lucania Earthquake, inferred from surface observations. J. Geophys. Res. 1990, 95, 15319. [CrossRef] 
62. Cello, G.; Deiana, G.; Ferelli, L.; Marchegiani, L.; Maschio, L.; Mazzoli, S.; Michetti, A.; Serva, L.; Tondi, E.; Vittori, T. Geological constraints for earthquake faulting studies in the Colfiorito area (Central Italy). J. Seismol. 2000, 4, 357-364. [CrossRef]

63. Vittori, E.; Di Manna, P.; Blumetti, A.M.; Comerci, V.; Guerrieri, L.; Esposito, E.; Michetti, A.M.; Porfido, S.; Piccardi, L.; Roberts, G.P. Surface faulting of the 6 April 2009 Mw 6.3 L'Aquila earthquake in Central Italy. Bull. Seismol. Soc. Am. 2011, 101, 1507-1530. [CrossRef]

64. Dolce, M.; Di Bucci, D. Comparing recent Italian earthquakes. Bull. Earthq. Eng. 2017, 15, 497-533. [CrossRef]

65. Martinelli, G.; Dadomo, A.; Italiano, F.; Petrini, R.; Slejko, F.F. Geochemical monitoring of the 2012 Po Valley seismic sequence: A review and update. Chem. Geol. 2017, 469, 147-162. [CrossRef]

66. Chiaraluce, L.; Di Stefano, R.; Tinti, E.; Scognamiglio, L.; Michele, M.; Casarotti, E.; Cattaneo, M.; De Gori, P.; Chiarabba, C.; Monachesi, G.; et al. The 2016 Central Italy seismic sequence: A first look at the mainshocks, aftershocks, and source models. Seismol. Res. Lett. 2017, 88, 757-771. [CrossRef]

67. Civico, R.; Pucci, S.; Villani, F.; Pizzimenti, L.; De Martini, P.M.; Nappi, R.; Group, O.E.W. Surface ruptures following the 30 October $2016 \mathrm{Mw} 6.5$ Norcia earthquake, Central Italy. J. Maps 2018, 14, 151-160. [CrossRef]

68. Villani, F.; Civico, R.; Pucci, S.; Pizzimenti, L.; Nappi, R.; De Martini, P.M. A database of the coseismic effects following the 30 October 2016 Norcia earthquake in Central Italy. Sci. Data 2018, 5, 180049. [CrossRef] [PubMed]

69. ITHACA Working Group (2019). ITHACA (ITaly HAzard from CApable faulting), A database of active capable faults of the Italian territory. Version December 2019. ISPRA Geological Survey of Italy. Available online: http://sgi2.isprambiente.it/ithacaweb/Mappatura.aspx (accessed on 20 May 2020).

70. Toutain, J.P.; Munoz, M.; Poitrasson, F.; Lienard, A.C. Springwater chloride ion anomaly prior to a ML $=5.2$ Pyrenean earthquake. Earth Planet. Sci. Lett. 1997, 149, 113-119. [CrossRef]

71. Yechieli, Y.; Bein, A. Response of groundwater systems in the Dead Sea Rift Valley to the Nuweiba earthquake: Changes in head, water chemistry, and near-surface effects. J. Geophys. Res. Solid Earth 2002, 107, ETG 4-1-ETG 4-10. [CrossRef]

72. Charmoille, A.; Fabbri, O.; Mudry, J.; Guglielmi, Y.; Bertrand, C. Post-seismic permeability change in a shallow fractured aquifer following a ML 5.1 earthquake (Fourbanne karst aquifer, Jura outermost thrust unit, eastern France). Geophys. Res. Lett. 2005, 32. [CrossRef]

73. Pasvanoglu, S.; Canik, B.; Rosen, M.R. Hydrogeology and possible effects of the Mw 7.4 Marmara Earthquake (17 August 1999) on the spring waters in the Orhangazi-Bursa area, Turkey. J. Geol. Soc. India 2004, 63, 313-322.

74. Falcone, R.A.; Carucci, V.; Falgiani, A.; Manetta, M.; Parisse, B.; Petitta, M.; Rusi, S.; Spizzico, M.; Tallini, M. Changes on groundwater flow and hydrochemistry of the Gran Sasso carbonate aquifer after 2009 L'Aquila earthquake. Ital. J. Geosci. 2012, 131, 459-474.

75. Martinelli, G. Contributions to a History of Earthquake Prediction Research. Seismol. Res. Lett. 2000, 71, 583-588. [CrossRef]

76. Martinelli, G. Previous, current, and future trends in research into earthquake precursors in geofluids. Geoscience 2020, 10, 189. [CrossRef]

77. Dall'Aglio, M. Earthquake prediction by hydrogeochemical methods. Soc. Ital. Mineral. Petrol. 1976, 32, 421-436.

78. Esposito, E.; Pece, R.; Porfido, S.; Tranfaglia, G. Hydrological anomalies connected to earthquakes in southern Apennines (Italy). Nat. Hazards Earth Syst. Sci. 2001, 1, 137-144. [CrossRef]

79. Celico, P.; De Gennaro, M.; Ghiara, M.; Stanzione, D. Variazioni geochimiche nelle acque della valle del Sele dopo l'evento sismico del 23/11/80 in Irpinia. Rend. Soc. Geol. It 1981, 4, 137-139.

80. Di Bello, G.; Ragosta, M.; Heinicke, J.; Koch, U.; Lapenna, V.; Piscitelli, S.; Macchiato, M.; Martinelli, G. Time dynamics of background noise in geoelectrical and geochemical signals: An application in a seismic area of Southern Italy. Nuovo Cim. Soc. Ital. Fis. C 1998, 21, 609-629.

81. Italiano, F.; Martelli, M.; Martinelli, G.; Nuccio, P.M.; Paternoster, M. Significance of earthquake-related anomalies in fluids of Val D'Agri (Southern Italy). Terra Nov. 2001, 13, 249-257. [CrossRef]

82. Lapenna, V.; Martinelli, G.; Telesca, L. Long-range correlation analysis of earthquake-related geochemical variations recorded in Central Italy. Chaos Solitons Fractals 2004, 21, 491-500. [CrossRef]

83. Favara, R.; Italiano, F.; Martinelli, G. Earthquake-induced chemical changes in the thermal waters of the Umbria region during the 1997-1998 seismic swarm. Terra Nov. 2001, 13, 227-233. [CrossRef] 
84. Quattrocchi, F. In search of evidence of deep fluid discharges and pore pressure evolution in the crust to explain the seismicity style of the Umbria-Marche 1997-1998 seismic sequence (Central Italy). Ann. Geofis. 1999, 42, 609-636.

85. Caracausi, A.; Italiano, F.; Martinelli, G.; Paonita, A.; Rizzo, A. Long-term geochemical monitoring and extensive/compressive phenomena: Case study of the Umbria Region (Central Apennines, Italy). Ann. Geophys. 2005, 48, 43-53.

86. Heinicke, J.; Italiano, F.; Lapenna, V.; Martinelli, G.; Nuccio, P.M. Coseismic geochemical variations in some gas emissions of Umbria region (Central Italy). Phys. Chem. Earth Part A Solid Earth Geod. 2000, 25, 289-293. [CrossRef]

87. Italiano, F.; Caracausi, A.; Favara, R.; Martinelli, P.I.G. Geochemical Monitoring of Cold Waters during Seismicity: Implications for Earthquake-induced Modification in Shallow Aquifers. Terr. Atmos. Ocean. Sci. 2005, 16, 709. [CrossRef]

88. De Gregorio, S.; Federico, C.; Cappuzzo, S.; Favara, R.; Giudice, G.; Gurrieri, S.; Boschi, E. Stress-induced temperature variations in groundwater of the Monferrato area (North-Western Italy). Geofluids 2012, 12, 142-149. [CrossRef]

89. Federico, C.; Pizzino, L.; Cinti, D.; De Gregorio, S.; Favara, R.; Galli, G.; Giudice, G.; Gurrieri, S.; Quattrocchi, F.; Voltattorni, N. Inverse and forward modelling of groundwater circulation in a seismically active area (Monferrato, Piedmont, NW Italy): Insights into stress-induced variations in water chemistry. Chem. Geol. 2008, 248, 14-39. [CrossRef]

90. La Vigna, F.; Carucci, V.; Mariani, I.; Minelli, L.; Pascale, F.; Mattei, M.; Mazza, R.; Tallini, M. Intermediate-field hydrogeological response induced by L'Aquila earthquake: The acque albule hydrothermal system (Central Italy). Ital. J. Geosci. 2012, 131, 475-485.

91. Galassi, D.M.P.; Lombardo, P.; Fiasca, B.; Di Cioccio, A.; Di Lorenzo, T.; Petitta, M.; Di Carlo, P. Earthquakes trigger the loss of groundwater biodiversity. Sci. Rep. 2014, 4, 6273. [CrossRef]

92. Dadomo, A.; Lemmi, M.; Martinelli, G.; Menichetti, M.; Telesca, L. Springwater continuous monitoring in the L'Aquila area in concomitance with the April 2009 seismic swarm in Central Italy: Constraining factors to possible deep-seated fluid emissions. Chem. Geol. 2013, 339, 169-176. [CrossRef]

93. Bonfanti, P.; Genzano, N.; Heinicke, J.; Italiano, F.; Martinelli, G.; Pergola, N.; Telesca, L.; Tramutoli, V. Evidence of $\mathrm{CO}$ 2-gas emission variations in the central Apennines (Italy) during the L'Aquila seismic sequence (March-April 2009). Boll. Geofis. Teor. Appl. 2012, 53, 147-168.

94. Quattrocchi, F.; Pizzi, A.; Gori, S.; Boncio, P.; Voltattorni, N.; Sciarra, A. The contribution of fluid geochemistry to define the structural patterns of the 2009 L'Aquila seismic source. Ital. J. Geosci. 2012, 131, 448-457.

95. Chiodini, G.; Caliro, S.; Cardellini, C.; Frondini, F.; Inguaggiato, S.; Matteucci, F. Geochemical evidence for and characterization of $\mathrm{CO}_{2}$ rich gas sources in the epicentral area of the Abruzzo 2009 earthquakes. Earth Planet. Sci. Lett. 2011, 304, 389-398. [CrossRef]

96. Ciarletti, M.; Plastino, W.; Peresan, A.; Nisi, S.; Copia, L.; Panza, G.F.; Povinec, P.P. Uranium groundwater monitoring and seismic analysis: A case study of the Gran Sasso hydrogeological basin, Italy. Pure Appl. Geophys. 2016, 173, 1079-1095. [CrossRef]

97. Plastino, W.; Povinec, P.P.; De Luca, G.; Doglioni, C.; Nisi, S.; Ioannucci, L.; Balata, M.; Laubenstein, M.; Bella, F.; Coccia, E. Uranium groundwater anomalies and L'Aquila earthquake, 6 April 2009 (Italy). J. Environ. Radioact. 2010, 101, 45-50. [CrossRef] [PubMed]

98. Italiano, F.; Liotta, M.; Martelli, M.; Martinelli, G.; Petrini, R.; Riggio, A.; Rizzo, A.L.; Slejko, F.; Stenni, B. Geochemical features and effects on deep-seated fluids during the May-June 2012 southern Po Valley seismic sequence. Ann. Geophys. 2012, 55, 815-821.

99. Fidani, C.; Balderer, W.; Leuenberger, F. The Possible Influences of the 2012 Modena Earthquakes on the Fluorescence Spectra of Bottled Mineral Water. Hydrol. Curr. Res. 2017, 8, 288.

100. Pierotti, L.; Botti, F.; D'Intinosante, V.; Facca, G.; Gherardi, F. Anomalous $\mathrm{CO}_{2}$ content in the Gallicano thermo-mineral spring (Serchio Valley, Italy) before the 21 June 2013, Alpi Apuane earthquake $(\mathrm{M}=5.2)$. Phys. Chem. Earth 2015, 85-86, 131-140. [CrossRef]

101. Barberio, M.D.; Barbieri, M.; Billi, A.; Doglioni, C.; Petitta, M. Hydrogeochemical changes before and during the 2016 Amatrice-Norcia seismic sequence (Central Italy). Sci. Rep. 2017, 7, 11735. [CrossRef] 
102. Boschetti, T.; Barbieri, M.; Barberio, M.D.; Billi, A.; Franchini, S.; Petitta, M. $\mathrm{CO}_{2}$ Inflow and Elements Desorption Prior to a Seismic Sequence, Amatrice-Norcia 2016, Italy. Geochem. Geophys. Geosystems 2019, 20, 2303-2317. [CrossRef]

103. Martini, C. Signals in water-The deep originated $\mathrm{CO}_{2}$ in the Peschiera-Capone acqueduct in relation to monitoring of seismic activity in Central Italy. Acque Sotter. Ital. J. Groundw. 2017, 20. [CrossRef]

104. Chiodini, G.; Cardellini, C.; Di Luccio, F.; Selva, J.; Frondini, F.; Caliro, S.; Rosiello, A.; Beddini, G.; Ventura, G. Correlation between tectonic $\mathrm{CO}_{2}$ Earth degassing and seismicity is revealed by a 10 -year record in the Apennines, Italy. Sci. Adv. 2020, 6, eabc2938. [CrossRef]

105. Martinelli, G.; Dadomo, A.; Heinicke, J.; Italiano, F.; Petrini, R.; Pierotti, L.; Riggio, A.; Santulin, M.; Slejko, F.F.; Tamaro, A. Recovery and processing of hydrological and hydrogeochemical parameters for researches on earthquake short-term precursors in Italy. Boll. Geofis. Teor. Appl. 2015, 56, 115-128.

106. Muir-Wood, R.; King, G.C.P. Hydrological signatures of earthquake strain. J. Geophys. Res. Solid Earth 1993, 98, 22035-22068. [CrossRef]

107. Reddy, D.V.; Nagabhushanam, P.; Sukhija, B.S. Earthquake (M 5.1) induced hydrogeochemical and $\delta 180$ changes: Validation of aquifer breaching_mixing model in Koyna, India. Geophys. J. Int. 2011, 184, 359-370. [CrossRef]

108. Montgomery, D.R.; Manga, M. Streamflow and water well responses to earthquakes. Science 2003, 300, 2047-2049. [CrossRef]

109. Hosono, T.; Hartmann, J.; Louvat, P.; Amann, T.; Washington, K.E.; West, A.J.; Okamura, K.; Böttcher, M.E.; Gaillardet, J. Earthquake-induced structural deformations enhance long-term solute fluxes from active volcanic systems. Sci. Rep. 2018, 8, 14809. [CrossRef] [PubMed]

110. Italiano, F.; Martinelli, G.; Plescia, P. $\mathrm{CO}_{2}$ Degassing over Seismic Areas: The Role of Mechanochemical Production at the Study Case of Central Apennines. Pure Appl. Geophys. 2008, 165, 75-94. [CrossRef]

111. Cardellini, C.; Chiodini, G.; Frondini, F.; Avino, R.; Bagnato, E.; Caliro, S.; Lelli, M.; Rosiello, A. Monitoring diffuse volcanic degassing during volcanic unrests: The case of Campi Flegrei (Italy). Sci. Rep. 2017, 7, 6757. [CrossRef]

112. Violay, M.; Nielsen, S.; Spagnuolo, E.; Cinti, D.; Di Toro, G.; Di Stefano, G. Pore fluid in experimental calcite-bearing faults: Abrupt weakening and geochemical signature of co-seismic processes. Earth Planet. Sci. Lett. 2013, 361, 74-84. [CrossRef]

113. Paudel, S.R.; Banjara, S.P.; Wagle, A.; Freund, F.T. Earthquake chemical precursors in groundwater: A review. J. Seismol. 2018, 22, 1293-1314. [CrossRef]

114. Plastino, W.; Bella, F. Radon groundwater monitoring at underground laboratories of Gran Sasso (Italy). Geophys. Res. Lett. 2001, 28, 2675-2677. [CrossRef]

115. Wang, C.-H.; Wang, C.-Y.; Kuo, C.-H.; Chen, W.-F. Some isotopic and hydrological changes associated with the 1999 Chi-Chi earthquake, Taiwan. Isl. Arc 2005, 14, 37-54. [CrossRef]

116. Claesson, L.; Skelton, A.; Graham, C.; Mörth, C.M. The timescale and mechanisms of fault sealing and water-rock interaction after an earthquake. Geofluids 2007, 7, 427-440. [CrossRef]

117. Mastrorillo, L.; Saroli, M.; Viaroli, S.; Banzato, F.; Valigi, D.; Petitta, M. Sustained post-seismic effects on groundwater flow in fractured carbonate aquifers in Central Italy. Hydrol. Process. 2020, 34, 1167-1181. [CrossRef]

118. Rohatgi, A. WebPlotDigitizer 2019. Available online: https://automeris.io/WebPlotDigitizer (accessed on 15 November 2019).

119. Hevia, A.; Sánchez-Salguero, R.; Camarero, J.J.; Buras, A.; Sangüesa-Barreda, G.; Galván, J.D.; Gutiérrez, E. Towards a better understanding of long-term wood-chemistry variations in old-growth forests: A case study on ancient Pinus uncinata trees from the Pyrenees. Sci. Total Environ. 2018, 625, 220-232. [CrossRef] [PubMed]

120. Binda, G.; Pozzi, A.; Livio, F. An integrated interdisciplinary approach to evaluate potentially toxic element sources in a mountainous watershed. Environ. Geochem. Health 2020, 42, 1255-1272. [CrossRef] [PubMed]

121. Binda, G.; Pozzi, A.; Livio, F.; Piasini, P.; Zhang, C. Anomalously high concentration of Ni as sulphide phase in sediment and in water of a mountain catchment with serpentinite bedrock. J. Geochem. Explor. 2018, 190, 58-68. [CrossRef]

122. Gambillara, R.; Terrana, S.; Giussani, B.; Monticelli, D.; Roncoroni, S.; Martin, S. Investigation of tectonically affected groundwater systems through a multidisciplinary approach. Appl. Geochem. 2013, 33, 13-24. [CrossRef] 
123. Dossi, C.; Ciceri, E.; Giussani, B.; Pozzi, A.; Galgaro, A.; Viero, A.; Viganò, A. Water and snow chemistry of main ions and trace elements in the karst system of Monte Pelmo massif (Dolomites, Eastern Alps, Italy). Mar. Freshw. Res. 2007, 58, 649-656. [CrossRef]

124. Giussani, B.; Roncoroni, S.; Recchia, S.; Pozzi, A. Bidimensional and multidimensional Principal Component Analysis in long term atmospheric monitoring. Atmosphere 2016, 7, 155. [CrossRef]

125. Hartmann, J.; Berner, Z.; Stüben, D.; Henze, N. A statistical procedure for the analysis of seismotectonically induced hydrochemical signals: A case study from the Eastern Carpathians, Romania. Tectonophysics 2005, 405, 77-98. [CrossRef]

126. Quattrocchi, F.; Calcara, M. Test-sites for earthquake prediction experiments within the Colli Albani region. Phys. Chem. Earth 1998, 23, 915-920. [CrossRef]

127. Banzato, F.; Barberio, M.D.; Campagnoli, L.; Passaretti, S.; Pollastrelli, A.; Doglioni, C.; Petitta, M. Groundwater changes in the Nera river valley due to the August-October 2016 seismic sequence in central Italy. In Proceedings of the Flowpath 2017-National Meeting on Hydrogeology, Cagliari, Italy, 14-16 June 2017.

128. Hammond, D.E.; Teng, T.L.; Miller, L.; Haraguchi, G. A search for Co-variance among seismicity, groundwater chemistry, and groundwater radon in southern California. Geophys. Res. Lett. 1981, 8, 445-448. [CrossRef]

129. Chiodini, G.; Frondini, F.; Cardellini, C.; Parello, F.; Peruzzi, L. Rate of diffuse carbon dioxide Earth degassing estimated from carbon balance of regional aquifers: The case of central Apennine, Italy. J. Geophys. Res. Solid Earth 2000, 105, 8423-8434. [CrossRef]

130. Huang, F.; Li, M.; Ma, Y.; Han, Y.; Tian, L.; Yan, W.; Li, X. Studies on earthquake precursors in China: A review for recent 50 years. Geod. Geodyn. 2017, 8, 1-12. [CrossRef]

131. Geller, R.J. Earthquake prediction: A critical review. Geophys. J. Int. 1997, 131, 425-450. [CrossRef]

132. Geller, R.J.; Jackson, D.D.; Kagan, Y.Y.; Mulargia, F. Earthquakes cannot be predicted. Science 1997, $275,1616$. [CrossRef]

133. Riggio, A.; Santulin, M. Earthquake forecasting: A review of radon as seismic precursor. Boll. Geofis. Teor. Appl. 2015, 56, 95-114.

134. Hartmann, J.; Levy, J.K. Hydrogeological and gasgeochemical earthquake precursors-A review for application. Nat. Hazards 2005, 34, 279-304. [CrossRef]

135. Nakagawa, K.; Yu, Z.-Q.; Berndtsson, R.; Hosono, T. Temporal characteristics of groundwater chemistry affected by the 2016 Kumamoto earthquake using self-organizing maps. J. Hydrol. 2019, 582, 124519. [CrossRef]

136. Ciancabilla, N.; Ditta, M.; Italiano, F.; Martinelli, G. The Porretta thermal springs (Northern Apennines): Seismogenic structures and long-term geochemical monitoring. Ann. Geophys. 2007, 50, 513-526.

137. Gherardi, F.; Pierotti, L. The suitability of the Pieve Fosciana hydrothermal system (Italy) as a detection site for geochemical seismic precursors. Appl. Geochem. 2018, 92, 166-179. [CrossRef]

138. Ingebritsen, S.E.; Manga, M. Earthquakes: Hydrogeochemical precursors. Nat. Geosci. 2014, 7, 697. [CrossRef]

139. Salvi, S.; Quattrocchi, F.; Brunori, C.A.; Doumaz, F.; Angelone, M.; Billi, A.; Buongiorno, F.; Funiciello, R.; Guerra, M.; Mele, G.; et al. A multidisciplinary approach to earthquake research: Implementation of a Geochemical Geographic Information System for the Gargano Site, Southern Italy. Nat. Hazards 1999, 20, 255-278. [CrossRef]

140. Riggio, A.; Sancin, S. Radon measurements in Friuli (N.E. Italy) and earthquakes: First results. Boll. Geofis. Teor. Appl. 2005, 46, 47-58.

141. Comerci, V.; Doglioni, C.; Italiano, F.; Baiocco, F.; Barberio, M.D.; Caracausi, A.; Cuiuli, E.; Guerra, M.; Infantino, V.; Insolvibile, M.; et al. Towards a national hydrogeochemical monitoring system: A further tool to investigate geological hazards. In Proceedings of the International Conference on Gas Geochemistry, Palermo \& Milazzo, Italy, 30 September-5 October 2019.

Publisher's Note: MDPI stays neutral with regard to jurisdictional claims in published maps and institutional affiliations. 